\title{
Effects of macro metals on alkaline phosphatase activity under conditions of sulfide accumulation
}

\author{
Guoqiang Zhao a,b, Yanqing Sheng a,*, Changyu Li ${ }^{\mathrm{a}, \mathrm{b}}$, Qunqun Liu ${ }^{\mathrm{a}, \mathrm{b}}$ \\ ${ }^{a}$ Research Center for Coastal Environment Engineering Technology of Shandong Province, Yantai Institute of Coastal Zone Research, Chinese Academy of Sciences, Yantai, China \\ ${ }^{\mathrm{b}}$ University of Chinese Academy of Sciences, Beijing, China
}

\section{H I G H L I G H T S}

- $\mathrm{Al}^{3+}, \mathrm{Fe}^{2+}, \mathrm{Ca}^{2+}$ can inhibit alkaline phosphatase (AP) activities.

- Excess $\mathrm{S}^{2-}$ reduces AP activities by removing $\mathrm{Zn}^{2+}$ active sites.

- The inhibition of $\mathrm{Al}^{3+}$ and $\mathrm{Fe}^{2+}$ on $\mathrm{AP}$ activities can be alleviated by $\mathrm{S}^{2-}$.

- Organic P monoester excluding recalcitrant $\mathrm{P}$ chelates can be hydrolyzed by AP.

\section{A R T I C L E I N F O}

\section{Article history:}

Received 1 July 2019

Received in revised form 25 August 2019

Accepted 26 August 2019

Available online 27 August 2019

Editor: F.M. Tack

\section{Keywords:}

Alkaline phosphatase

Macro metal

Sulfate reduction

Organic phosphorus
G R A P H I C A L A B S T R A C T
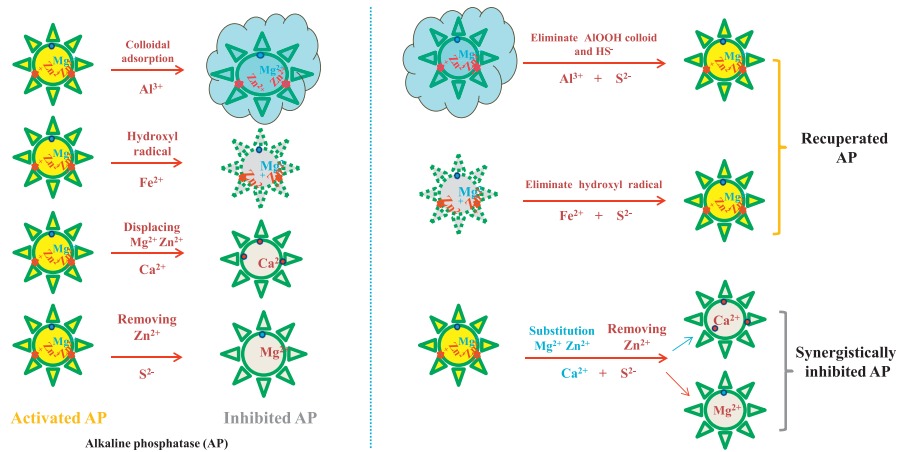

\section{A B S T R A C T}

Alkaline phosphatase (AP) is commonly found in aquatic ecosystems as an extracellular enzyme closely related to the biogeochemical cycling of phosphorus. Although the AP activity (APA) is conventionally thought to be a main response to $\mathrm{PO}_{4}^{3-}$ starvation, significant effects of macro metal elements $(\mathrm{Al}, \mathrm{Fe}$, and $\mathrm{Ca}$ ) and $\mathrm{S}$ on the APA were found in this study. The APA was reduced by Al primarily through the adsorption of the enzyme onto AlOOH colloids. $\mathrm{Fe}^{2+}$ inhibited the APA via a mechanism involving free radical oxidation. The main mechanism by which $\mathrm{Ca}^{2+}$ inhibited the APA was by competing with $\mathrm{Mg}^{2+}$ and $\mathrm{Zn}^{2+}$ for the active sites of the enzyme. Excessive $\mathrm{S}^{2-}$ could reduce the APA by removing $\mathrm{Zn}^{2+}$ from the active sites of the enzyme. The inhibition of APA could be reversed if some metal ions (e.g., $\mathrm{Fe}^{2+}$ ) were precipitated by $\mathrm{S}^{2-}$ under reducing conditions. Therefore, in anaerobic ecosystems, the effects of macro metals on APA under conditions of sulfide accumulation may have innovative implications for phosphorus management.

(c) 2019 Elsevier B.V. All rights reserved.

\section{Introduction}

Organic phosphorus (OP) can be hydrolyzed into $\mathrm{PO}_{4}^{3-}$, which constitutes a large proportion of the total $\mathrm{P}$ in aquatic ecosystems

\footnotetext{
* Corresponding author.

E-mail addresses: gqzhao@yic.ac.cn (G. Zhao), yqsheng@yic.ac.cn (Y. Sheng), cyli@yic.ac.cn (C. Li), qunqliu@yic.ac.cn (Q. Liu).
}

(Ahlgren et al., 2005). The hydrolysis of OP is closely related to its fraction and structure; OP hydrolysis has been widely studied by sequential extraction procedures and solution ${ }^{31} \mathrm{P}$ nuclear magnetic resonance spectroscopy ( ${ }^{31} \mathrm{P}$ NMR), as well as enzymatic hydrolysis experiments (Zhu et al., 2013). Generally, OP can be classified as readily labile OP (LOP), moderately labile OP (MLOP), and non-labile OP (NLOP) based on the fractionation method (Ivanoff et al., 1998). The species and classes of OP, which mainly comprise phosphonate, orthophosphate 
monoester (e.g., $\alpha$ - or $\beta$-glycerophosphate, mononucleotides, choline phosphate, inositol hexaphosphate, and glucose-6-phosphate), and orthophosphate diester (e.g., DNA, phospholipids, and RNA), can be characterized by ${ }^{31}$ P NMR (W. Zhang et al., 2016). Alkaline phosphatase (AP, EC 3.1.3.1) is commonly found in aquatic ecosystems as an ectoenzyme and extracellular enzyme that is secreted by phytoplankton and bacteria (Dai et al., 2017). AP can hydrolyze labile orthophosphate monoesters into $\mathrm{PO}_{4}^{3-}$ and organic matter (Zhou et al., 2002). However, excess of $\mathrm{PO}_{4}^{3-}$ can rapidly inhibit the AP activity (APA) (Huang et al., 2018). Therefore, APA has been used as an indicator for the degree of eutrophication in aquatic ecosystems (X. Zhang et al., 2016). However, many factors, such as the amount of trace metals, suspended particulate matter, and pH, can significantly affect the APA (Labry et al., 2016; Tan et al., 2017; Tian et al., 2018; X. Zhang et al., 2016). Thus, the identification of factors that influence OP hydrolysis by AP is crucial for understanding the dynamics of phosphorus in aquatic ecosystems.

AP is a homodimeric, nonspecific phosphomonoesterase with different active sites (Takano et al., 2006). Each active site has three closely spaced metal-binding sites identified as M1, M2, and M3, and/or an additional non-catalytic binding site (M4) (Millan, 2006). Two zinc ions $\left(\mathrm{Zn}^{2+}\right)$ occupy the M1 and M2 sites, and a magnesium ion $\left(\mathrm{Mg}^{2+}\right)$ occupies the M3 site (Tang et al., 2019). The M4 is a peripheral binding site occupied by $\mathrm{Ca}^{2+}$; it is conserved in human and mouse APs (Le Du and Millan, 2002). However, the M4 site is not present in bacterial enzymes (Le Du et al., 2001; Mornet et al., 2001). Generally, AP derived from Escherichia coli has been selected as a research object rather than mammal-derived APs, because in natural ecosystems, APs are mainly secreted by microorganisms (Dai et al., 2017). AP-mediated catalysis requires M1 site occupancy and is greatly enhanced by M2 site occupancy (Hjorleifsson and Asgeirsson, 2016). The AP-catalyzed reaction shows a maximum rate at an alkaline $\mathrm{pH}$ (Holtz and Kantrowitz, 1999). Furthermore, sulfonamides can interact with the active sites in AP occupied by $\mathrm{Zn}^{2+}$, resulting in the inhibition of APA (Salar et al., 2017). Arsenate can inhibit APA through its strong binding to AP and/or its structural similarity with $\mathrm{PO}_{4}^{3-}$ (Tian et al., 2018). AP can also be strongly adsorbed by goethite and montmorillonite, resulting in some active sites being occupied by organic matter and/or mineral ions (Zhu et al., 2016). Similarly, the inhibition of APA can also be achieved by Cd via the reduction of the enzyme's affinity to substrates, as well as the decrease of the maximum reaction velocity (Tan et al., 2018). Although the effects of some trace metal ions ( $\mathrm{n}, \mathrm{Mn}, \mathrm{Co}, \mathrm{Ni}, \mathrm{Cd}$, and As ions) on APA have been intensively studied (Brunel and Cathala, 1973), most studies have focused on APs secreted by large mammals. However, AP in aquatic ecosystems is mainly derived from phytoplankton and bacteria (Dai et al., 2017; Labry et al., 2016; Ragot et al., 2015). The molecular weight, structure, and activity of microbial APs are different from those of mammalian APs (Hoylaerts et al., 2015). In addition to trace metals, macro metals such as Al, Fe, and Ca may also affect the APA. However, there are only a few relevant studies on APs in aquatic ecosystems, especially with regards to the effects of these metals on the activity of microbial APs.

Sulfate reduction is an important biogeochemical process related to metal ion cycling and the toxicity of sulfides. Many trace metal ions and freely dissolved sulfides (referred to as $\mathrm{S}^{2-}$ ) can be eliminated by precipitation processes (Jong and Parry, 2003). During anerobic sulfate reduction, the accumulated $\mathrm{S}^{2-}$ would couple with $\mathrm{Fe}$, promoting $\mathrm{PO}_{4}^{3-}$ release from Fe oxides and/or hydroxides (Kraal et al., 2017). Generally, $\mathrm{S}^{2-}$ is recognized as a biological toxin that poisons cells and nerves, and inhibits the activity of enzymes due to its acidity and by inducing oxidative stress (Chen et al., 2019; Zhou et al., 2018). However, most studies have merely focused on oxidases, peroxidases, and some enzymes related to gene expression in plants and animals, rather than microbial APs (Corpas et al., 2019; Nicholls et al., 2013; Thompson et al., 2003). Although Zavaczki et al. have reported the toxicity of $\mathrm{S}^{2-}$ towards APA, the damage caused by $\mathrm{S}^{2-}$ to the active sites of AP is still unclear (Zavaczki et al., 2011). Therefore, understanding the effects of $S^{2-}$ and major metal ions on the activity of microbial APs may provide significant insights into the mechanism underlying OP hydrolysis during hypoxic conditions.

The objectives of this study were to: (1) investigate the effects of APA gradients on the hydrolysis efficiency of OP; (2) explore the mechanism underlying the effects of the macro metal elements $\mathrm{Al}$, Fe, and $\mathrm{Ca}$ on the APA; and (3) study the inhibition and/or recovery of APA under conditions of sulfate reduction. This research will provide new insights into the regulation of the APA in anerobic ecosystems under conditions of sulfate reduction.

\section{Materials and methods}

\subsection{Sediment sampling and chemicals}

The surface sediments $(0-10 \mathrm{~cm})$ were collected from the Jiehe River $(\mathrm{JH})$, a heavily polluted river with abundant OP and metal ion levels in the sediments (Zhao et al., 2019). The black and foul-smelling sediments were collected with a Van Veen grab and the samples were immediately (in 1 min) stored in plastic zip lock bags (flushed with nitrogen prior to use), kept cold using ice packs, and transported to the laboratory within $12 \mathrm{~h}$, where they were frozen in a refrigerator at $-20{ }^{\circ} \mathrm{C}$ until analysis. The sediments were lyophilized and homogenized prior to analysis. Details regarding the location of sample collection (JH5) and the sediment properties are illustrated in Fig. S1 and Table S1. The AP from Escherichia coli (Sigma P5931) and standard substances used for obtaining the ${ }^{31} \mathrm{P}$ NMR spectra were purchased from Sigma-Aldrich.

\subsection{Enzymatic hydrolysis experiment}

\subsubsection{Hydrolysis of $O P$ and inactivation of $A P$}

To compare the effects of AP on the hydrolysis of OP, four sets of slurries were maintained in parallel; four of the 4.0-g portions of the lyophilized sediment samples, which were passed through a 100-mesh sieve, were added into $200 \mathrm{~mL}$ of 0 unit $(\mathrm{U}) \mathrm{mL}^{-1}, 0.2 \mathrm{U} \mathrm{mL}^{-1}, 2 \mathrm{U} \mathrm{mL}^{-1}$, and $20 \mathrm{U} \mathrm{mL}^{-1}$ AP solutions. The AP solutions were prepared in Tris- $\mathrm{HCl}$ buffer $(0.1 \mathrm{M}, \mathrm{pH} 8)$. All slurries were incubated at $28-30{ }^{\circ} \mathrm{C}$ in duplicate for $24 \mathrm{~h}$. At specific time points $(0,2,4,6,4,6,10,16$, and $24 \mathrm{~h}), 2.0 \mathrm{~mL}$ of each mixture was sampled and immediately centrifuged (4000 rpm, $15 \mathrm{~min}$ ). Approximately $1 \mathrm{~mL}$ of the supernatants was analyzed for $\mathrm{PO}_{4}^{3-}$ production using the molybdenum blue method. The residual supernatants were analyzed for APA by a spectrophotometric method (Sayler et al., 1979). Detailed information regarding these procedures is provided in the supporting information.

All enzymatic hydrolysis experiments focused on the enzymatic response to actual environmental conditions; thus, the incubation conditions were kept as close as possible to the natural conditions $(\mathrm{pH} 8$, temperature $28-30{ }^{\circ} \mathrm{C}$ ).

\subsubsection{Sequential extraction of $O P$ and ${ }^{31} P N M R$ determination}

At the end of the enzymatic hydrolysis experiment, the remainder of the slurry in each reaction system was lyophilized to obtain the dry sediments that had been hydrolyzed by AP. The OP in the lyophilized sediments was analyzed using the optimized Ivanoff method and ${ }^{31} \mathrm{P}$ NMR (Zhao et al., 2019). Detailed information regarding the procedures of the Ivanoff method and ${ }^{31} \mathrm{P}$ NMR analyses is provided in the supporting information.

\subsection{Enzymatic activity experiment}

\subsubsection{Determination of the interference of APA by metal ions and sulfide}

To understand the interaction of AP with macro metal ions ( $\mathrm{Al}, \mathrm{Fe}$, and $\mathrm{Ca}$ ions) in aquatic ecosystems under conditions of sulfate reduction, batches of enzymatic activity experiments were conducted in parallel. Five groups comprising samples in $10-\mathrm{mL}$ reaction tubes were set; AP solutions (0.1 M Tris- $\mathrm{HCl}, \mathrm{pH} 8.0$ ) were added into each tube in 
parallel ( to obtain a final concentration of $1 \mathrm{U} \mathrm{mL}^{-1}$ ). Then, $\mathrm{Al}^{3+}{ }_{-}, \mathrm{Fe}^{2+}-$, $\mathrm{Ca}^{2+}{ }_{-}, \mathrm{SO}_{4}^{2-}$-, and $\mathrm{S}^{2-}$-containing solutions were mixed with the samples from the five groups. In each group, the concentration gradient of each ion $\left(\mathrm{Al}^{3+}, \mathrm{Fe}^{2+}, \mathrm{Ca}^{2+}, \mathrm{SO}_{4}^{2-}\right.$, and $\left.\mathrm{S}^{2-}\right)$ was set to 1,3 , and $6 \mathrm{mM}$. Four sets of experiments were performed in $10-\mathrm{mL}$ reaction tubes to compare the APA changes after the reaction of the free dissolved sulfides with the metal ions $\left(\mathrm{Al}^{3+}, \mathrm{Fe}^{2+}\right.$, and $\left.\mathrm{Ca}^{2+}\right)$. First, $1 \mathrm{~mL}$ of $10 \mathrm{mM} \mathrm{S}^{2-}$ solution, followed by $1 \mathrm{~mL}$ of $10 \mathrm{mM} \mathrm{Al}^{3+}, \mathrm{Fe}^{2+}$, and $\mathrm{Ca}^{2+}$ solutions, were added into each tube in parallel. Then, $7 \mathrm{~mL}$ of $0.1 \mathrm{M}$ Tris- $\mathrm{HCl}$ buffer solution $(\mathrm{pH} 8)$ was added into each tube to attain final $\mathrm{Al}^{3+}, \mathrm{Fe}^{2+}, \mathrm{Ca}^{2+}$, and $\mathrm{S}^{2-}$ concentrations of $1 \mathrm{mM}$, and the reaction was initiated by adding $1 \mathrm{~mL}$ of $10 \mathrm{U} \mathrm{mL}^{-1} \mathrm{AP}$ solution into each tube, to attain a final enzyme concentration of $1 \mathrm{U} \mathrm{mL}^{-1}$. A control experiment was conducted in parallel with the addition of $1 \mathrm{U} \mathrm{mL}^{-1} \mathrm{AP}$.

The $\mathrm{AP}, \mathrm{AlCl}_{3}, \mathrm{FeCl}_{2}, \mathrm{CaCl}_{2}, \mathrm{Na}_{2} \mathrm{SO}_{4}$, and $\mathrm{Na}_{2} \mathrm{~S}$ solutions were prepared in $0.1 \mathrm{M}$ Tris- $\mathrm{HCl}$ buffer with a final $\mathrm{pH}$ of 8 . Milli-Q water was purged with nitrogen prior to use. To maintain a reducing environment in the reaction tubes, the Tris- $\mathrm{HCl}$ buffer was mixed with $10 \%$ (wt\%) ascorbic acid solution at a ratio of 50:1 ( v/v). All samples were incubated at $28-30{ }^{\circ} \mathrm{C}$ for $24 \mathrm{~h}$ in a sealed bag filled with nitrogen. After incubation, $1 \mathrm{~mL}$ of the supernatants from each reaction mixture was sampled for the determination of the APA.

\subsubsection{Identification of metal sulfide products}

In the presence of dissolved sulfides, the metal ions $\left(\mathrm{Al}^{3+}, \mathrm{Fe}^{2+}, \mathrm{Ca}^{2}\right.$ ${ }^{+}$) may precipitate as $\mathrm{Al}-\mathrm{S}, \mathrm{Fe}-\mathrm{S}$, and $\mathrm{Ca}-\mathrm{S}$, respectively. To study the mechanism underlying the removal of metal ions from the reaction system by dissolved sulfides, the precipitates were collected by filtering the samples through a $0.45-\mu \mathrm{m}$ membrane (Pall ${ }^{\circledR}, \mathrm{GFF}$ ) at the end of the experiment, rinsed with ultrapure water, and lyophilized for further identification using scanning electron microscopy (SEM), energy dispersive $\mathrm{X}$-ray spectrometry (EDS), and X-ray diffraction (XRD). Although there was no precipitation in the tube containing $\mathrm{Ca}^{2+}$ following the addition of $\mathrm{S}^{2-}$, the clear solution was filtered through the $0.45-\mu \mathrm{m}$ membrane and the $\mathrm{Ca}^{2+}$ levels were determined. Control experiments without $\mathrm{S}^{2-}$ addition were also performed in parallel.

To study the effect of $\mathrm{S}^{2-}$ on aluminum colloids, the particle sizes of the precipitates formed in the $\mathrm{AlCl}_{3}$ solution-containing sample with and/or without the addition of $\mathrm{Na}_{2} \mathrm{~S}$ were investigated. The $\mathrm{Na}_{2} \mathrm{~S}$ solution was added into the $\mathrm{AlCl}_{3}$ solution to yield final $\mathrm{AlCl}_{3}$ and $\mathrm{Na}_{2} \mathrm{~S}$ concentrations of $10 \mathrm{mM}$. A control was prepared without $\mathrm{Na}_{2} \mathrm{~S}$ addition, where only the particle size of the precipitates was determined and the other conditions were kept constant throughout the experiment. The $\mathrm{Na}_{2} \mathrm{~S}$ and $\mathrm{AlCl}_{3}$ solutions were prepared with Milli-Q water. The final $\mathrm{pH}$ of the $\mathrm{Na}_{2} \mathrm{~S}$ and $\mathrm{AlCl}_{3}$ solutions was adjusted to 8.0 using $\mathrm{NaOH}$. Subsequently, the particle size of the precipitate in the supernatant was analyzed by using a laser particle-size analyzer (Malvern 2000F, Malvern, UK) after the centrifugation of the supernatant at $4000 \mathrm{rpm}$ for $15 \mathrm{~min}$.

\subsubsection{Enzyme deactivation by $\mathrm{Na}_{2} \mathrm{~S}$}

To investigate the mechanism underlying the deactivation of AP by dissolved sulfides, AP solution was added into $10-\mathrm{mL}$ tubes to attain a final concentration of $5 \mathrm{U} \mathrm{mL}^{-1}$. Then, $\mathrm{Na}_{2} \mathrm{~S}$ solution was added into these tubes to attain a final $\mathrm{S}^{2-}$ concentration of $10 \mathrm{mM}$. Control experiments without $\mathrm{Na}_{2} \mathrm{~S}$ addition were also performed in parallel. After incubation at $28-30{ }^{\circ} \mathrm{C}$ for $24 \mathrm{~h}$, the solution in each tube was centrifuged at $13,000 \mathrm{rpm}$ for $15 \mathrm{~min}$ and then filtered through a $0.45-\mu \mathrm{m}$ membrane. Concentrations of $\mathrm{Zn}^{2+}$ and $\mathrm{Mg}^{2+}$ in the filtered solutions were measured using inductively coupled plasma-mass spectrometry (ICPMS, PerkinElmer ELAN DRC II, US).

\subsection{Extraction of sediments using $\mathrm{Na}_{2} \mathrm{~S}$}

The sediments were extracted with different concentrations of $\mathrm{Na}_{2} \mathrm{~S}$ to investigate whether the APA can be reactivated after the metal ions were removed by free dissolved sulfides. Seven sets of $\mathrm{Na}_{2} \mathrm{~S}$ concentration gradient experiments were established in parallel: $4.0 \mathrm{~g}$ of the sediments were extracted with $200 \mathrm{~mL}$ of $\mathrm{Na}_{2} \mathrm{~S}$ solutions $(0 \mathrm{mM}, 5 \mathrm{mM}$, $10 \mathrm{mM}, 30 \mathrm{mM}, 60 \mathrm{mM}, 100 \mathrm{mM}$, and $200 \mathrm{mM})$; the $\mathrm{S}^{2-}$ contents corresponded to $0,1,2,6,12,20$, and $40 \mathrm{mmol}$, respectively. The slurries were incubated at $28-30{ }^{\circ} \mathrm{C}$ for $24 \mathrm{~h}$ with slight shaking ( $\left.180 \mathrm{rpm}\right)$. The control sample without $\mathrm{Na}_{2} \mathrm{~S}(0 \mathrm{mM})$ was extracted using the Tris- $\mathrm{HCl}$ buffer. At the end of the experiment, $2 \mathrm{~mL}$ of slurry from each conical flask was centrifuged at $4000 \mathrm{rpm}$ for $15 \mathrm{~min}$. The amounts of $\mathrm{Al}^{3+}$, $\mathrm{Fe}^{2+}$, and $\mathrm{Ca}^{2+}$ in the supernatants were analyzed inductively coupled plasma optical emission spectroscopy (ICP-OES) to characterize the removal efficiency of the metal ions by the dissolved sulfides.

The remaining portions of the slurries were lyophilized to obtain the dry sediments that had been immobilized by $\mathrm{Na}_{2} \mathrm{~S}$. Then, $4.0 \mathrm{~g}$ of the lyophilized sediments were added into seven 200 -mL aliquots of AP solution ( $1 \mathrm{U} \mathrm{mL}^{-1}, \mathrm{pH} 8$ ), which was prepared using the Tris- $\mathrm{HCl}$ buffer. Then, the seven slurries were incubated at $28-30{ }^{\circ} \mathrm{C}$ for $24 \mathrm{~h}$. Data regarding the APA from the seven reaction systems were collected at 0 , $2,4,6,10,16$, and $24 \mathrm{~h}$ after the reaction to study the effects of sulfate reduction on the APA under reducing conditions.

\subsection{Simulation of reaction equilibria by visual MINTEQ}

The thermodynamic states of $\mathrm{Al}^{3+}, \mathrm{Fe}^{2+}$, and $\mathrm{Ca}^{2+}$ with and/or without the addition of $\mathrm{S}^{2-}$ at a $\mathrm{pH}$ of 8 and $28-30{ }^{\circ} \mathrm{C}$ were simulated by using the software Visual MINTEQ 3.0. As per the simulation conditions, the $\mathrm{pH}$ and temperature were fixed. The thermodynamic state of each ion in the solution was calculated as the solubility product (Ksp), ion activity product (IAP), and saturation index (SI), according to the Visual MINTEQ software (Liu et al., 2018). The following criteria were used: $\mathrm{SI}<0$, no precipitate; $\mathrm{SI}=0$, equilibrium; and $\mathrm{SI}>0$, generating precipitates (Migaszewski et al., 2018).

$S I=\log \frac{I A P}{K_{s p}}$

\subsection{Statistical analysis}

Significance of data were analyzed using one-way analysis of variance (ANOVA) followed by means testing between treated groups and the control and/or between different treated groups by using SPSS 20.0 (IBM SPSS Inc.). All significance levels mentioned in the text are $\mathrm{p}$ $<0.05$.

\section{Results}

\subsection{Release of $\mathrm{PO}_{4}^{3-}$ and $\mathrm{OP}$ hydrolysis}

Effects of APA gradients on the hydrolysis of OP in the sediments are shown in Fig. 1. Approximately 2 min after the hydrolysis experiment, the initial concentrations of the $\mathrm{PO}_{4}^{3-}$ released in the slurry following the addition of $0,0.2,2$, and $20 \mathrm{U} \mathrm{mL}^{-1}$ of AP were $0.59,0.62,0.70$, and $0.70 \mathrm{mg} \mathrm{L}^{-1}$, respectively. Compared to the control sample, the initial $\mathrm{PO}_{4}^{3-}$ concentration in the slurry following AP addition was significantly higher $(\mathrm{p}<0.05)$. Additionally, the $\mathrm{PO}_{4}^{3-}$-release rates in all samples abruptly increased within the first $2 \mathrm{~h}$, and then showed a slower increase until the 16 -h time point. After $16 \mathrm{~h}$, the concentration of $\mathrm{PO}_{4}^{3-}-\mathrm{P}$ following AP addition almost plateaued, while it still showed a slight increase in the control sample (from $2.1 \mathrm{mg} \mathrm{L}^{-1}$ to the final $2.2 \mathrm{mg} \mathrm{L}^{-1}$ ). At the end of the experiment, the average amounts of $\mathrm{PO}_{4}^{3-}$ in the slurries containing $0.2,2$, and $20 \mathrm{U} \mathrm{mL}^{-1}$ of AP were approximately $2.5,2.6$, and $2.7 \mathrm{mg} \mathrm{L}^{-1}$, respectively; they were much higher than the $\mathrm{PO}_{4}^{3-}$ concentration in the control sample $\left(2.2 \mathrm{mg} \mathrm{L}^{-1}\right)$.

The trend of APA variation with time during the OP hydrolysis experiment is presented in Fig. 2. The initial APA in the four centrifuged 


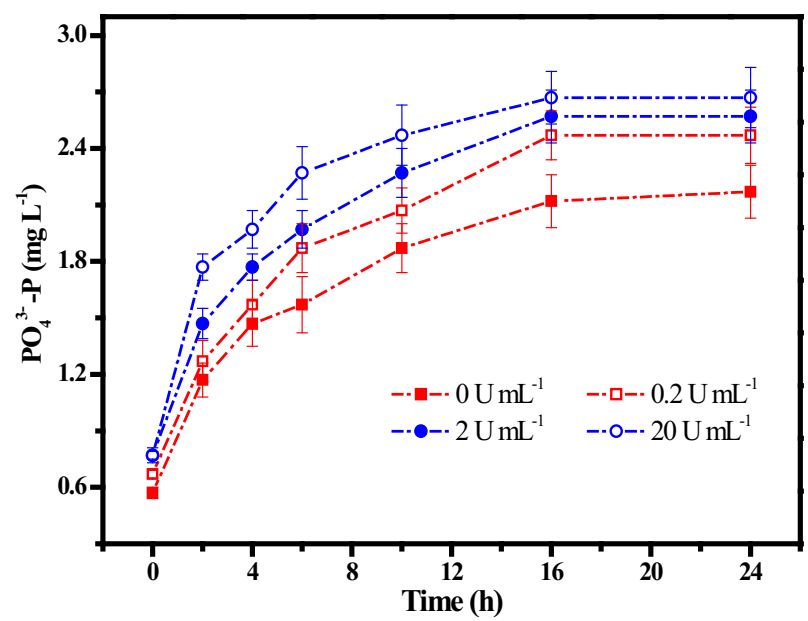

Fig. 1. Concentration of $\mathrm{PO}_{4}^{3-}$-P released from sediments during the hydrolysis by alkaline phosphatase (AP). Each value interval represents the average \pm standard deviation ( $\mathrm{n}=$ 3). Four parallel 4.0-g lyophilized sediments were extracted by $200 \mathrm{~mL}$ of $0,0.2,2 \mathrm{U}$ and $20 \mathrm{U} \mathrm{mL}^{-1} \mathrm{AP}$ solutions for $24 \mathrm{~h}$ at $28-30{ }^{\circ} \mathrm{C}$

slurries containing $0,0.2,2$, and $20 \mathrm{U} \mathrm{mL}^{-1}$ of AP was $0.27,410,6100$, and $15,000 \mathrm{mg} \mathrm{L}^{-1} \mathrm{~h}^{-1}$, respectively. The APA in the control sample (without AP addition) remained constant throughout the experiment. In contrast, the APA in the samples containing AP dropped significantly from 0 to $4 \mathrm{~h}$. The APA fluctuated within a narrow range after $16 \mathrm{~h}$ in the tubes containing 0.2 and $2 \mathrm{U} \mathrm{mL}^{-1}$ of AP. However, in the tube containing $20 \mathrm{U} \mathrm{mL}^{-1}$ of AP, the APA reached an equilibrium after $4 \mathrm{~h}$. At the end of the experiment, the final APA in the slurries containing $0,0.2$, 2 , and $20 \mathrm{U} \mathrm{mL}^{-1}$ of AP was $0.27,20,4300$, and $14,850 \mathrm{mg} \mathrm{L}^{-1} \mathrm{~h}^{-1}$, respectively.

The changes of OP speciation in the hydrolyzed sediments following treatment with AP are shown in Table S2. The concentration of $\mathrm{NaHCO}_{3}-$ OP (classified as labile OP) in the sediment not subjected to hydrolysis by AP was $42 \mathrm{mg} \mathrm{kg}^{-1}$, while it dropped down to $21,4.2$, and $4.2 \mathrm{mg} \mathrm{kg}^{-1}$ in the sediments hydrolyzed by the addition of $0.2,2$, and $20 \mathrm{U} \mathrm{mL}^{-1}$ of AP, respectively. Additionally, the concentrations of both $\mathrm{HCl}-\mathrm{OP}$ and Flv-OP, which were classified as moderately labile OP, in the hydrolyzed sediments decreased significantly $(\mathrm{p}<0.01)$. For $\mathrm{HCl}-$ OP and Flv-OP, the hydrolysis rates were $16 \%$ and $11 \%$, respectively, for $0.2 \mathrm{U} \mathrm{mL}^{-1}$ of $\mathrm{AP}, 33 \%$ and $17 \%$, respectively, for $2 \mathrm{U} \mathrm{mL}^{-1}$ of $\mathrm{AP}$, and $67 \%$ and $44 \%$, respectively, for $20 \mathrm{U} \mathrm{mL}^{-1}$ of AP. However, there was no significant drop in the concentrations of Hum-OP and $\mathrm{H}_{2} \mathrm{SO}_{4}{ }^{-}$ $\mathrm{OP}$, which were classified as non-labile OP, in the hydrolyzed sediments $(\mathrm{p}>0.1)$.

The recovery of $\mathrm{P}$ in the NaOH-EDTA extracts is shown in Table S3. The extraction efficiencies of both total $\mathrm{P}$ and OP with NaOH-EDTA were higher than $80 \%$ in the sediment, which indicated that most of the P compounds had been successfully extracted from the sediments into the supernatants for NMR analysis. The ${ }^{31} \mathrm{P}$ NMR spectra and integral results of $\mathrm{P}$ compounds are illustrated in Fig. 3 and Table S4, respectively. The NMR results illustrated that the contents of phosphonate, myo-IHP, and DNA did not significantly decrease after incubation with $2 \mathrm{U} \mathrm{mL}^{-1}$ of AP, compared to the control sample. However, the $\beta$-Gly and $\mathrm{PC}$ contents dropped from $1.62 \%$ and $0.42 \%$ to $1.02 \%$ and $0.35 \%$, respectively, after the hydrolysis with $2 \mathrm{U} \mathrm{mL}^{-1}$ of AP.

\subsection{Inhibition and reactivation of the APA}

The results showed that $\mathrm{Al}^{3+}, \mathrm{Fe}^{2+}, \mathrm{Ca}^{2+}, \mathrm{SO}_{4}^{2-}$, and $\mathrm{S}^{2-}$ could inhibit the APA, compared to the case for the control sample (Fig. 4). Among these ions, $\mathrm{Fe}^{2+}$ and $\mathrm{S}^{2-}$ had strong inhibitory effects on the APA, while $\mathrm{SO}_{4}^{2-}$ had a slight effect on the APA. The APA was reduced from $\sim 2400 \mathrm{mg} \mathrm{L}^{-1} \mathrm{~h}^{-1}$ in the control to $\sim 200 \mathrm{mg} \mathrm{L}^{-1} \mathrm{~h}^{-1}$ and $\sim 210 \mathrm{mg} \mathrm{L}^{-1} \mathrm{~h}^{-1}$ in the samples containing $1 \mathrm{mM}$ of Fe$^{2+}$ and $\mathrm{S}^{2-}$, respectively. The addition of $S^{2-}$ ameliorated the inhibition of APA by $\mathrm{Fe}^{2+}$ and $\mathrm{Al}^{3+}$. The inhibited APA in the sample containing $1 \mathrm{mM}$ of $\mathrm{Fe}^{2+}$ and $\mathrm{Al}^{3+}$ rose from $\sim 200 \mathrm{mg} \mathrm{L}^{-1} \mathrm{~h}^{-1}$ and $1500 \mathrm{mg} \mathrm{L}^{-1} \mathrm{~h}^{-1}$ to $\sim 560 \mathrm{mg} \mathrm{L}^{-1} \mathrm{~h}^{-1}$ and $2000 \mathrm{mg} \mathrm{L}^{-1} \mathrm{~h}^{-1}$, respectively, after the addition of $1 \mathrm{mM} \mathrm{S}^{2-}$. The inhibition of APA by $\mathrm{Ca}^{2+}$ could not be reversed, but was instead, more pronounced after the addition of $\mathrm{S}^{2-}$.

The characterization of the products of the reaction of $\mathrm{Al}^{3+}, \mathrm{Fe}^{2+}$, and $\mathrm{Ca}^{2+}$ with $\mathrm{S}^{2-}$ is presented in Fig. 5. The results depicted in Fig. 5A show that the precipitate from the sample in which $\mathrm{Al}^{3+}$ and $\mathrm{S}^{2-}$ were added was faint yellow. It was primarily composed of $\mathrm{C}, \mathrm{O}$, and $\mathrm{Al}$, with molar ratios of $13 \%, 70 \%$, and $16 \%$, respectively. The percentage of S was low (only $0.22 \%$ ). The precipitate in the sample containing $\mathrm{Al}$ was in a weak crystallinity phase, with a uniform and compact surface (Fig. 5B and E). The XRD spectrum confirmed that the precipitate was $\mathrm{Al}(\mathrm{OH})_{3}$ with $\mathrm{AlOOH}$ phases. In comparison, the product of the reaction between $\mathrm{Fe}^{2+}$ and $\mathrm{S}^{2-}$ in the enzymatic activity experiment was black, with a compact and striated surface. The main elements in the black precipitate were $\mathrm{C}, \mathrm{O}, \mathrm{Fe}$, and $\mathrm{S}$, with molar percentages of approximately 23\%,36\%, 17\%, and 20\%, respectively (Fig. 5D). This
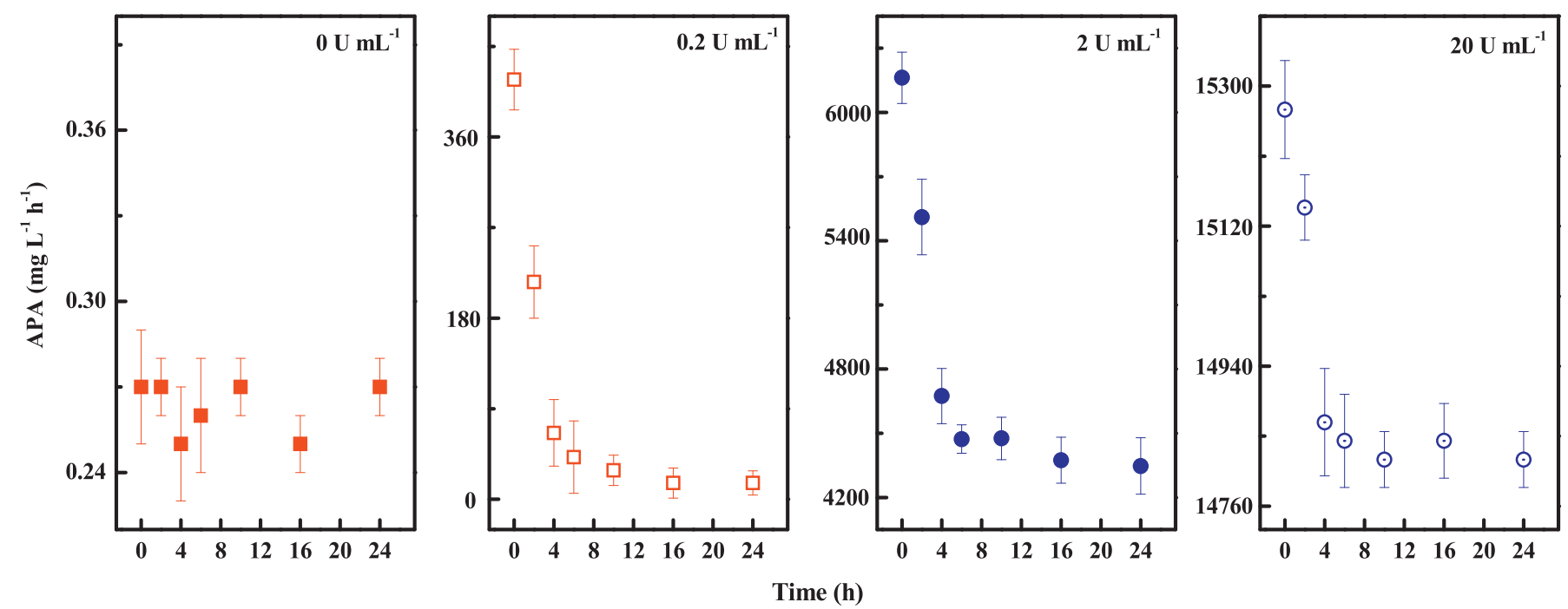

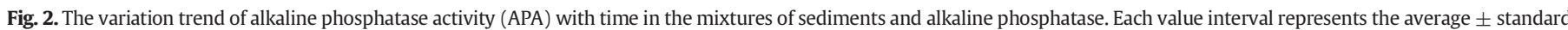
deviation $\left(\mathrm{n}=3\right.$ ). Four parallel $4.0 \mathrm{~g}$ of lyophilized sediment was extracted by $200 \mathrm{~mL}$ of $0,0.2,2$ and $20 \mathrm{U} \mathrm{mL}^{-1}$ alkaline phosphatase solutions, respectively, for $24 \mathrm{~h}$ at $28-30{ }^{\circ} \mathrm{C}$ 
(A) $\mathrm{LB}: 10 \mathrm{~Hz}$

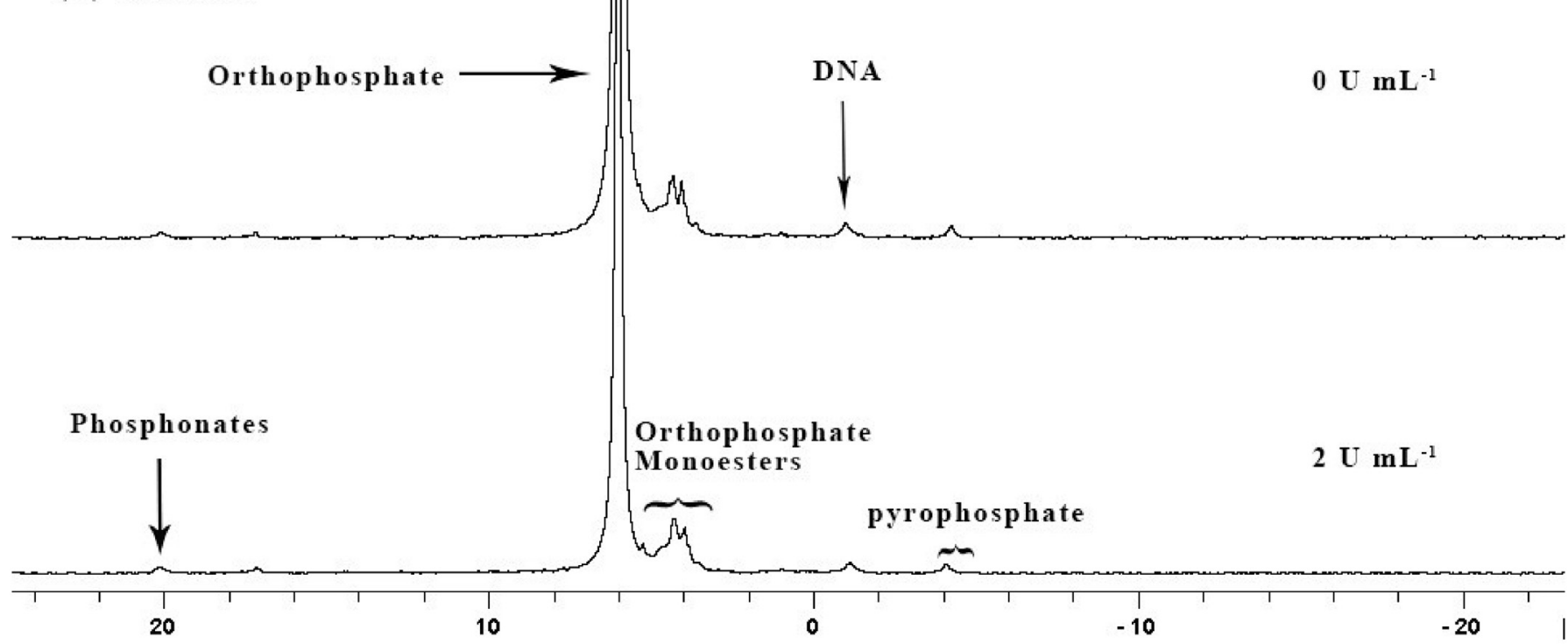

(B) LB: $1 \mathrm{~Hz}$

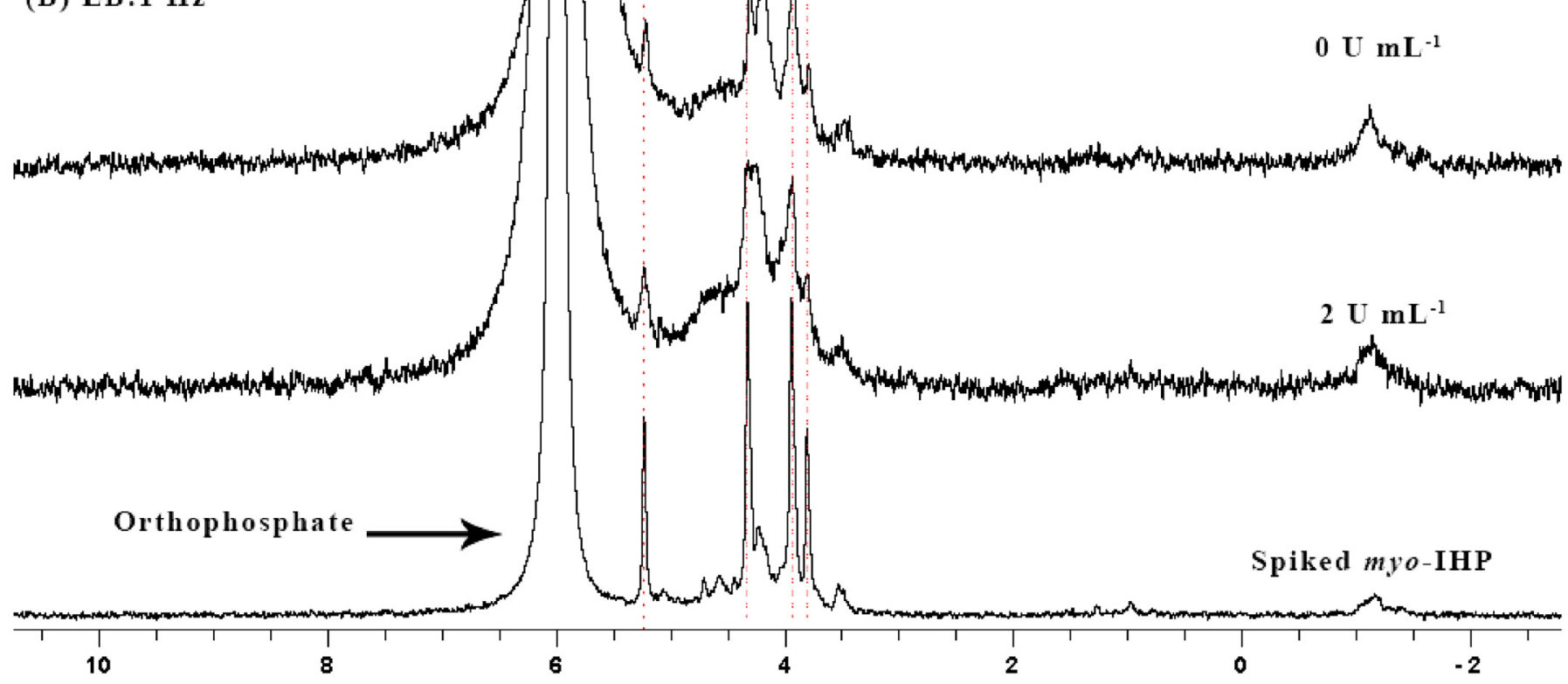

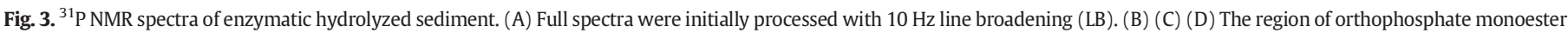

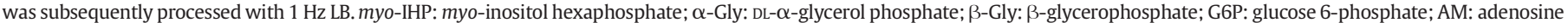
5' monophosphate; PC: phosphocholine; G1P: glucose-1-phosphate.

precipitate was in an amorphous phase (Fig. 5F) after the addition of organic matter (Tris and AP). Thus, even without the addition of organic matter, precipitates could still be generated in the samples containing $\mathrm{Fe}$ and $\mathrm{Al}$. The product of the reaction between $\mathrm{Al}$ and $\mathrm{S}$ was mainly composed of $\mathrm{AlOOH}$ (Fig. S2), while the precipitate generated from the reaction between $\mathrm{Fe}$ and $\mathrm{S}$ was likely $\mathrm{FeS}_{2}$ and $\mathrm{FeO}(\mathrm{OH})$ (Fig. S3). A detailed description of the identification of the precipitates generated without the addition of organic matter is provided in the supporting information. The content of $\mathrm{Ca}^{2+}$ in the filtrate remained constant after $\mathrm{Na}_{2} \mathrm{~S}$ addition, compared to the control sample (Fig. 5G).

As shown in Fig. 5, AlOOH colloids were probably generated in the sample containing $\mathrm{Al}^{3+}$. Additionally, the addition of $\mathrm{S}^{2-}$ may affect the formation of AlOOH colloids. Therefore, the particle size of precipitates formed in the sample containing $\mathrm{Al}^{3+}$ in the presence and/or absence of $\mathrm{S}^{2-}$ was analyzed using a laser particle analyzer. The results of the particle size determination are shown in Fig. 6. The particle size of the precipitates in the supernatant of the $\mathrm{AlCl}_{3}$-containing sample formed following $\mathrm{Na}_{2} \mathrm{~S}$ addition was smaller, and the particle size range of these precipitates was higher than that of the precipitates formed in the absence of $\mathrm{Na}_{2} \mathrm{~S}$ (Fig. 6A). The particle sizes of all the precipitates were $>200 \mathrm{~nm}$ in the supernatant containing $\mathrm{Na}_{2} \mathrm{~S}$, while those of the precipitates formed in the samples not containing $\mathrm{Na}_{2} \mathrm{~S}$ after centrifugation were $<100 \mathrm{~nm}$ (the scope of a colloid) (Fig. 6B).

The contents of $\mathrm{Zn}^{2+}$ and $\mathrm{Mg}^{2+}$ in AP were determined after the extraction using $\mathrm{Na}_{2} \mathrm{~S}$ to study whether the addition of $\mathrm{S}^{2-}$ could precipitate the $\mathrm{Zn}^{2+}$ and $\mathrm{Mg}^{2+}$ present in the active sites of AP. The concentrations of $\mathrm{Zn}^{2+}$ and $\mathrm{Mg}^{2+}$ in the active sites of AP in the presence and/or absence of $\mathrm{Na}_{2} \mathrm{~S}$ are shown in Fig. 7. The results showed that the contents of intrinsic $\mathrm{Zn}^{2+}$ and $\mathrm{Mg}^{2+}$ in the AP were 4.5 $\mu \mathrm{mol} \mathrm{L}{ }^{-1}$ and $1.5 \mu \mathrm{mol} \mathrm{L}{ }^{-1}$, respectively, without the $\mathrm{Na}_{2} \mathrm{~S}$ extraction 


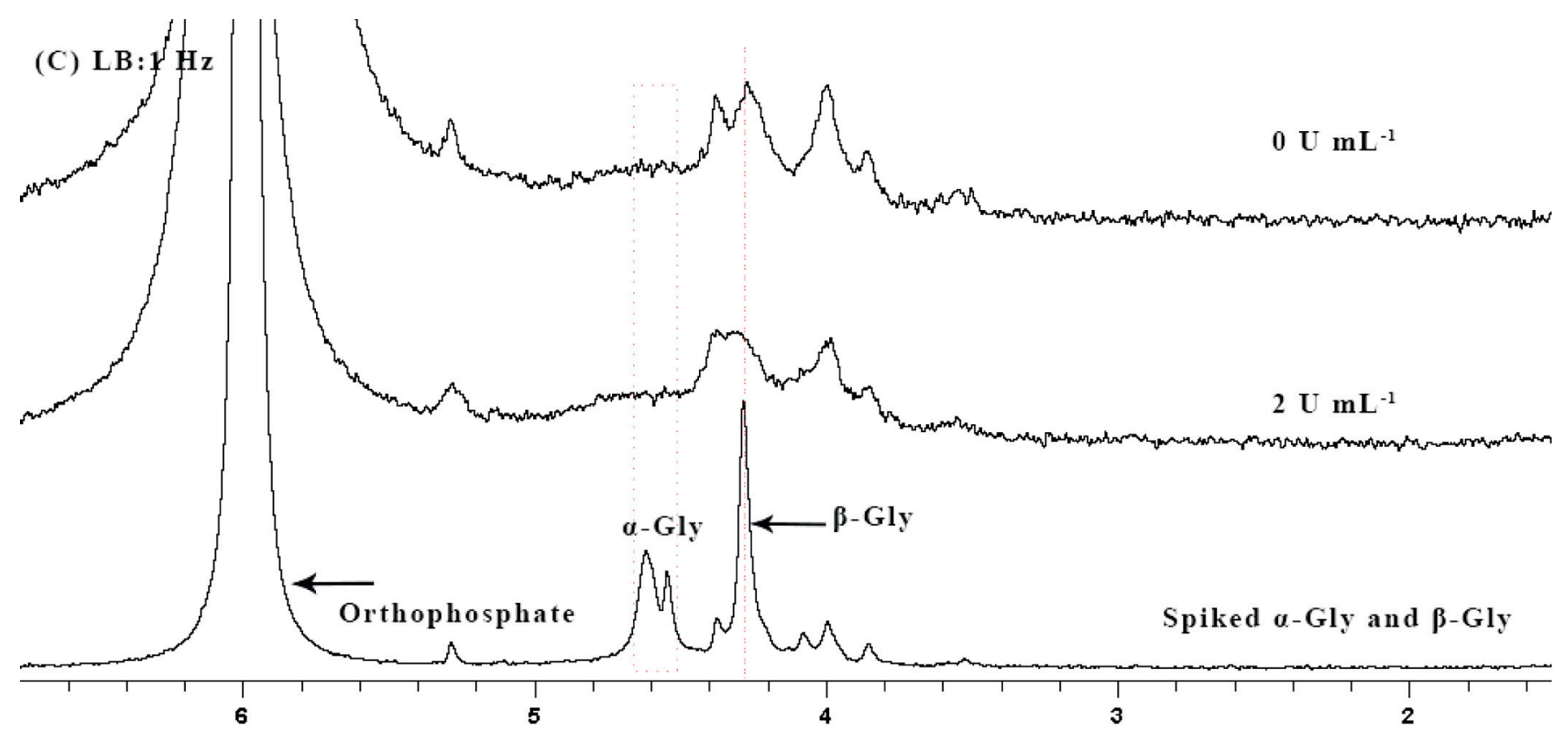

(D) $\mathrm{LB}: 1 \mathrm{~Hz}$

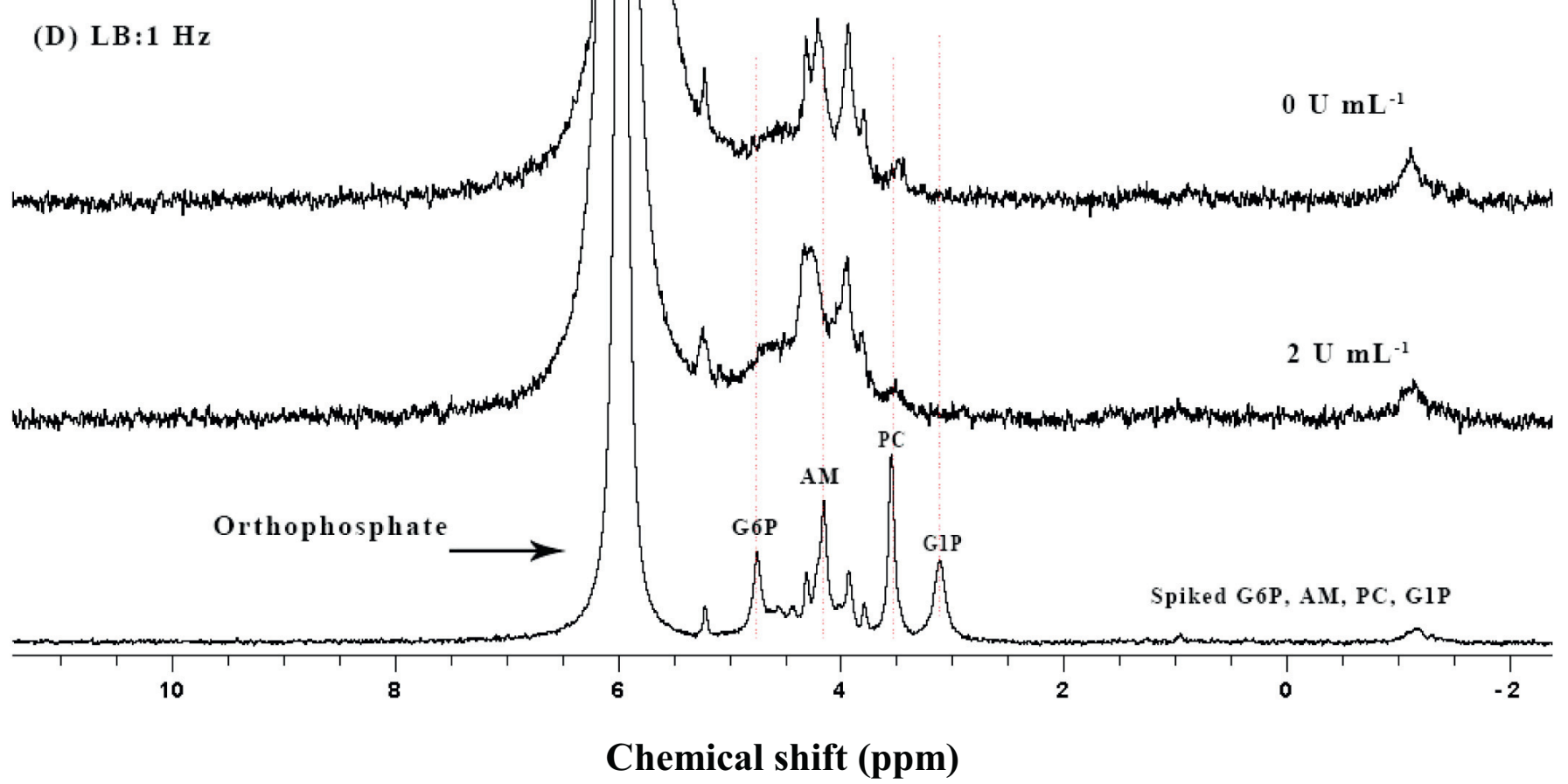

Fig. 3 (continued).

process. After the extraction with $\mathrm{S}^{2-}$, the $\mathrm{Zn}^{2+}$ content dropped to 1.5 $\mu \mathrm{mol} \mathrm{L}{ }^{-1}$ (67\% removal). However, the $\mathrm{Mg}^{2+}$ concentration remained constant before and after the extraction, showing that $\mathrm{Na}_{2} \mathrm{~S}$ addition had almost no influence on the $\mathrm{Mg}^{2+}$ content.

\subsection{Metal ion immobilization and APA changes}

Concentrations of $\mathrm{Fe}, \mathrm{Al}$, and $\mathrm{Ca}$ released from the sediments during the extraction process using $\mathrm{Na}_{2} \mathrm{~S}$ are shown in Fig. 8A. The concentration of $\mathrm{Al}$ in the supernatant significantly decreased as the content of $\mathrm{S}^{2-}$ increased. The immobilization efficiency of Al was $88 \%$ when the $\mathrm{S}^{2-}$ concentration was $100 \mathrm{mM}$; however, it only increased by $8 \%$ when the $\mathrm{S}^{2-}$ concentration was $200 \mathrm{mM}$, compared to the case when $100 \mathrm{mM} \mathrm{S}^{2-}$ was present. The amount of Fe in the supernatant presented a peak when the concentration of $\mathrm{S}^{2-}$ was $10 \mathrm{mM}$. The amount of Fe was greater in the presence of $\mathrm{Na}_{2} \mathrm{~S}$ than that in the absence of $\mathrm{Na}_{2} \mathrm{~S}$ when the concentration of $\mathrm{S}^{2-}$ was $<30 \mathrm{mM}$. During the whole extraction process, the Al concentration decreased as the $\mathrm{S}^{2-}$ concentration increased, while the Ca concentration remained within a narrow range, with the average concentration being $11.3 \pm 0.38 \mathrm{mg} \mathrm{L}^{-1}$.

After the extraction, the slurries were lyophilized to obtain dry materials immobilized by $\mathrm{S}^{2-}$. Pictures of the lyophilized materials are presented in Fig. S4. The immobilized sediments were resuspended in a solution of $1 \mathrm{U} \mathrm{mL}^{-1}$ of AP to investigate the changes in the APA. The 


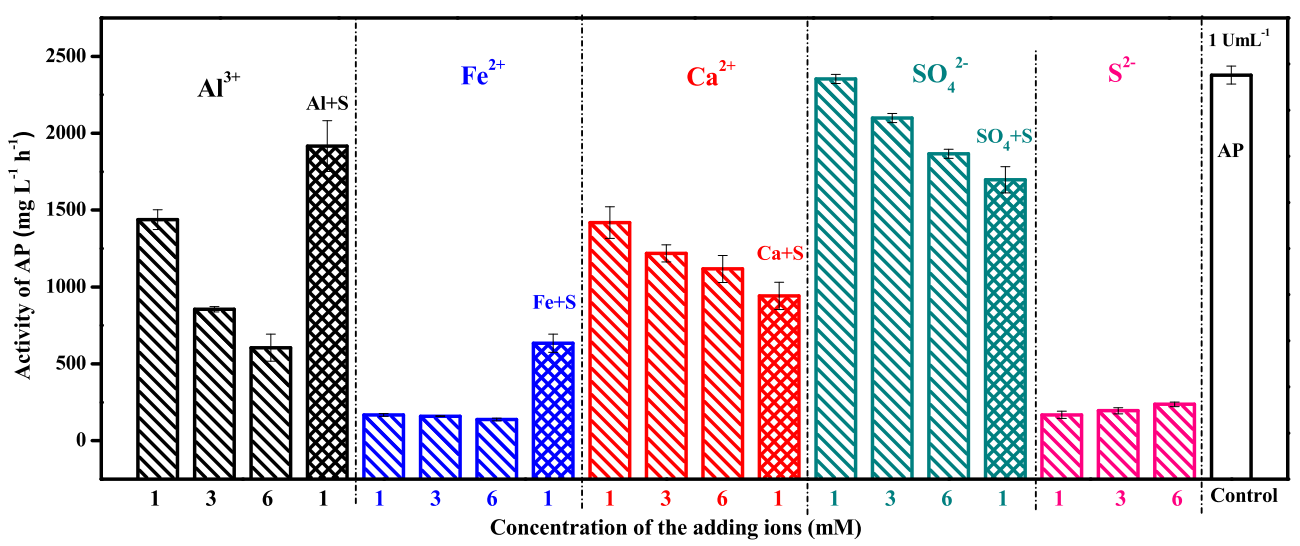

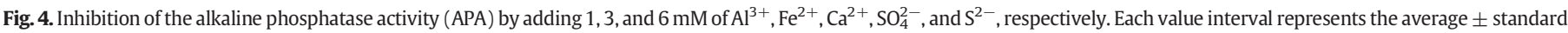

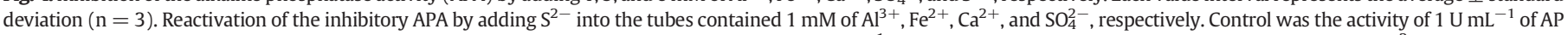

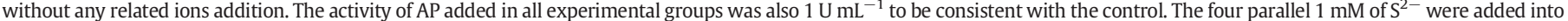
the tubes with the presence of $1 \mathrm{mM}$ of $\mathrm{Al}^{3+}, \mathrm{Fe}^{2+}, \mathrm{Ca}^{2+}$ and $\mathrm{SO}_{4}^{2-}$, respectively.

trend of APA variation with time in the resuspended mixtures is illustrated in Fig. 8B. The results showed that the initial APA in each supernatant from the resuspended slurries was different. The initial APA gradually increased as the $\mathrm{S}^{2-}$ concentration increased (5 to $100 \mathrm{mM}$ ), while it dropped when $\mathrm{S}^{2-}$ reached a concentration of $200 \mathrm{mM}$. Moreover, the initial APA in the sample without $\mathrm{Na}_{2} \mathrm{~S}$ was higher than that of the immobilized slurries as the $\mathrm{S}^{2-}$ concentration dropped below $30 \mathrm{mM}$. Additionally, the APA in the resuspended sediments significantly decreased in the first $6 \mathrm{~h}$; the APA decreased at differing rates. Generally, the largest decrease was seen in case of $S^{2-}$ concentrations below $60 \mathrm{mM}$. The decrease was clearly slowed when the $S^{2-}$ concentration increased to $100 \mathrm{mM}$, but accelerated again as the $\mathrm{S}^{2-}$ concentration reached $200 \mathrm{mM}$. After $6 \mathrm{~h}$, the APA in nearly all the samples was stable within a narrow range. The final APA in the seven slurries showed the following order: $100 \mathrm{mM} \mathrm{\textrm {S } ^ { 2 - }}$ $>200 \mathrm{mM} \mathrm{S}^{2-}>60 \mathrm{mM} \mathrm{S}^{2-}>0 \mathrm{mM} \mathrm{S}^{2-}>30 \mathrm{mM} \mathrm{S}^{2-}>10 \mathrm{mM} \mathrm{S}^{2-}$ $>5 \mathrm{mM} \mathrm{S}^{2-}$. The contents of $\mathrm{Fe}, \mathrm{Al}$, and $\mathrm{Ca}$ in the system were approximately $2.1,12.2$, and $0.8 \mathrm{mmol}$, as calculated from the metal contents described in Table S1.

\subsection{Thermodynamic analysis}

The concentration and state of metal ions in the presence and/or absence of $S^{2-}$ addition were calculated using the Visual MINITEQ software. As shown in Table S5, 99\% of the Al in the solution was precipitated as diaspore (AlOOH). Most of the Fe was present in the dissolved state $\left(\mathrm{Fe}^{2+}, 97 \%\right)$; only $3 \%$ was present as $\mathrm{Fe}(\mathrm{OH})_{2}$. The Ca content was stable, because $100 \%$ of the Ca was still in the form of $\mathrm{Ca}^{2+}$, showing no precipitation. The proportion and form of $\mathrm{Al}$ and $\mathrm{Ca}$ were stable after $\mathrm{S}^{2-}$ addition. All the added $\mathrm{S}^{2-}$ was present in the form of $\mathrm{S}^{2-}$ in the two samples containing Al and Ca. However, 99\% of the $\mathrm{Fe}^{2+}$ was removed from the solution as mackinawite (FeS) after $\mathrm{S}^{2-}$ addition. The concentrations of both $\mathrm{Fe}^{2+}$ and $\mathrm{S}^{2-}$ reduced significantly, down to $\sim 0.3 \%$.
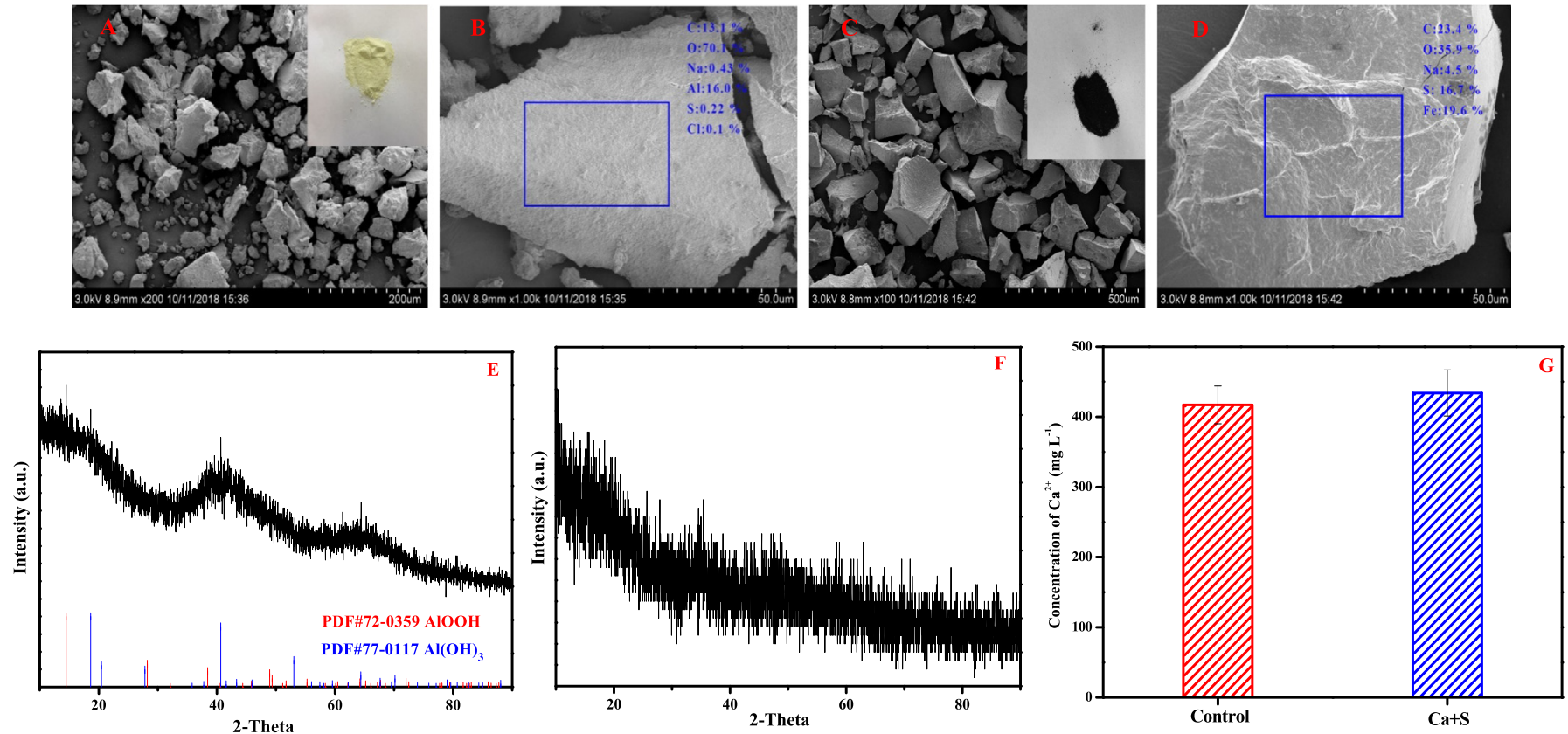

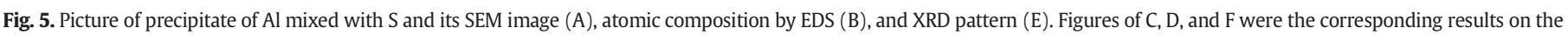
products of Fe reacted with $\mathrm{S}$. Changes in Ca contents of the filtered solution after the Ca and $\mathrm{S}$ reaction. Each value interval represents the average \pm standard deviation $(\mathrm{n}=3)(\mathrm{G})$. 

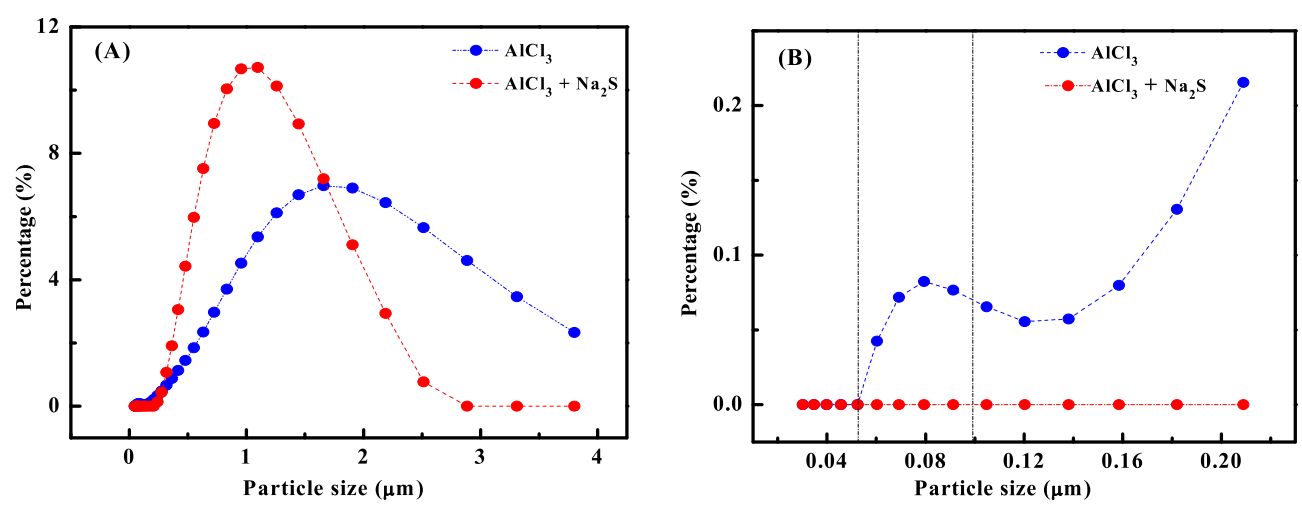

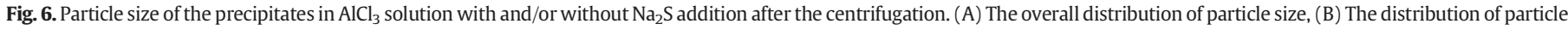

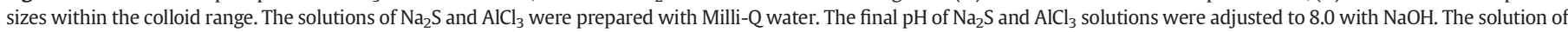

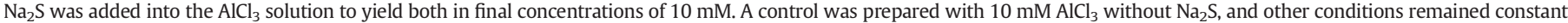
throughout the experiment.

\section{Discussion}

\subsection{Enzymatic hydrolysis and activity}

AP is a nonspecific phosphomonoesterase that can hydrolyze phosphate monoesters into $\mathrm{PO}_{4}^{3-}$ and organic matter. Therefore, both the concentration and release efficiency of $\mathrm{PO}_{4}^{3-}$ in slurries containing AP were higher than those in the control sample, indicating that AP enhanced the $\mathrm{PO}_{4}^{3-}$ release. Additionally, the content of the $\mathrm{PO}_{4}^{3-}$ in the slurries treated with AP was greater than that in the control at the first time point (about $2 \mathrm{~min}$ ), which indicated that the hydrolysis of OP by AP was rapid. A small amount of the OP that was adsorbed by the sediments was released into the AP solution during the mixing process. Then, the released OP could be rapidly decomposed into $\mathrm{PO}_{4}^{3-}$ and organic matter when it came in contact with the AP. The activity of AP gradually decreased with AP addition during the experiment; this explains why the rates of $\mathrm{PO}_{4}^{3-}$ release dropped significantly after $2 \mathrm{~h}$. Comparison of the hydrolysis efficiency of various fractions of OP (Table S2) revealed that $\mathrm{NaHCO}_{3}-\mathrm{OP}$ was the most easily degraded by $\mathrm{AP}$, followed by $\mathrm{HCl}-\mathrm{OP}$ and Flv-OP. Compared to the control sample, the extra $\mathrm{PO}_{4}^{3-}$ in the slurries containing AP was mainly produced by the hydrolysis of $\mathrm{NaHCO}_{3}-\mathrm{OP}, \mathrm{HCl}-\mathrm{OP}$, and Flv-OP. Most of the NLOP (Hum-OP and the $\mathrm{H}_{2} \mathrm{SO}_{4}-\mathrm{OP}$ ) could not be hydrolyzed into $\mathrm{PO}_{4}^{3-}$ by AP due to its stable structure (Lü et al., 2016). Because NLOP was mainly converted from the free labile OP associated with humic acid and/or metal ions $\left(\mathrm{Al}^{3+}, \mathrm{Fe}^{3+}, \mathrm{Fe}^{2+}\right.$, and $\left.\mathrm{Ca}^{2+}\right)$, it was recalcitrant to hydrolysis

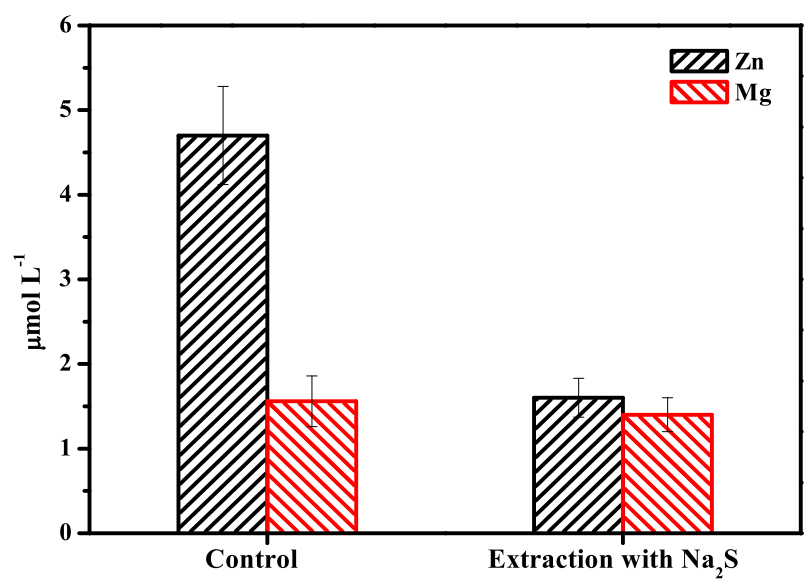

Fig. 7. Concentration of $\mathrm{Zn}$ and $\mathrm{Mg}$ was in alkaline phosphatase (AP) with and/or without the extraction by $\mathrm{Na}_{2} \mathrm{~S}$. Each value interval represents the average \pm standard deviation ( $\mathrm{n}$ $=3$ ). The control was $5 \mathrm{U} \mathrm{mL}^{-1}$ of AP solution without the addition of $\mathrm{Na}_{2} \mathrm{~S}$, while the other group was the parallel AP solution with the addition of the same $\mathrm{Na}_{2} \mathrm{~S}$. by AP (Zhu et al., 2015). Al, Fe, and Ca ions were present in high concentrations in the sediment (Table S1). Therefore, most of the NLOP may be strongly bound to the metal ions; this may explain why it is difficult to hydrolyze. As shown in Table S4, the DNA and myo-IHP could not be decomposed by AP because their hydrolysis requires phosphodiesterase and phytase, respectively (Shinohara et al., 2012; Turner et al., 2012). Although myo-IHP is an orthophosphate monoester, it was not decomposed by AP because it reacted with metal ions to form recalcitrant complexes (Turner et al., 2002). The results of the ${ }^{31}$ P NMR studies showed that most of the remaining $\beta$-Gly and PC could not be hydrolyzed by AP, which probably indicates that these P compounds had interacted with metal ions and/or humic acid, which made them resistant to enzymatic hydrolysis (Turner et al., 2012; Zhu et al., 2015). The phosphonate could not be hydrolyzed by AP due to the $\mathrm{C}-\mathrm{P}$ bond being more stable than the O-P bond (Luo et al., 2011). Specific phosphatases, rather than AP, would be required to break it down. Therefore, the OP species associated strongly with metal ions and/or humic acid, and DNA, myo-IHP, and phosphonate probably belong to the NLOP category.

As shown in Fig. 2, the activity of AP in each slurry gradually decreased during the experiments. This is partly because the gradually increasing $\mathrm{PO}_{4}^{3-}$ concentration in the AP solution can inhibit the APA (Huang et al., 2018). Another important reason for this is the immobilization of AP by the sediments. A previous report has suggested that when absorbed by sediments, the activity of AP could be reduced to $1.3 \%-5.3 \%$ of the activity of free AP (Zhu et al., 2016). APA can also be significantly reduced by trace metal ions in sediments, mainly through competition with the substrate for the active sites in AP, denaturation of the AP protein, and/or the generation of covalent bonds with the AP-substrate complexes (Vig et al., 2003). Various trace metal ions were abundant in the JH5 sediments (Zhang et al., 2014; Zhao et al., 2019). There were plenty of other light metals that are categorized as macroelements found in the sediments. The contents of these macroelements ( $\mathrm{Ca}, \mathrm{Fe}$, and $\mathrm{Ca}$ ) are higher than those of the trace metals by several orders of magnitude. Thus, whether and how they might affect the APA should be investigated.

\subsection{Mechanism of enzymatic inactivation and reactivation}

According to the thermodynamic analysis, nearly all the Al was converted into AlOOH during the incubation of the samples. There was a little amount of free $\mathrm{Al}^{3+}$ in the solution, accounting for $0.001 \%$ of the total $\mathrm{Al}$. Thus, the enzymatic inactivation observed following $\mathrm{Al}^{3+}$ addition could not have been caused by $\mathrm{Al}^{3+}$. Aluminum (hydr) oxides are often used to purify wastewater because they readily form colloids with a high surface area (Zamparas and Zacharias, 2014). Pollutant removal by $\mathrm{AlOOH}$ is mainly attributed to the bridging behavior of the 

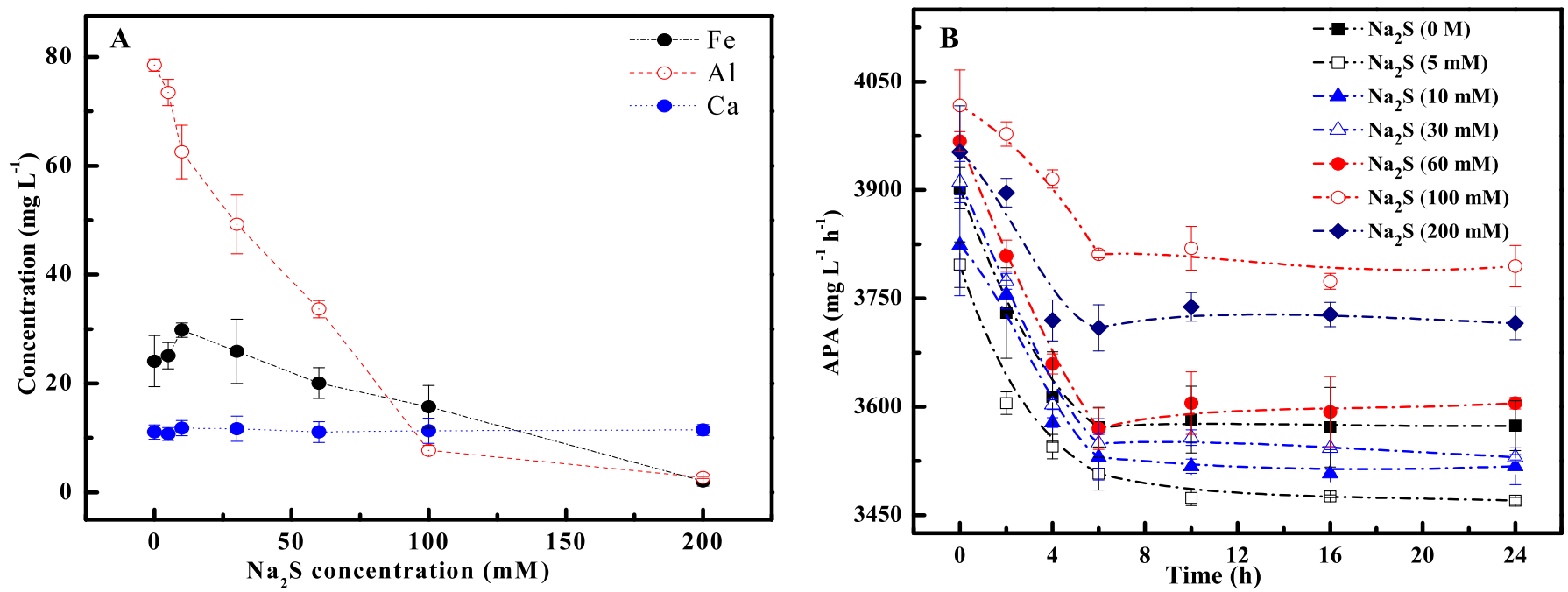

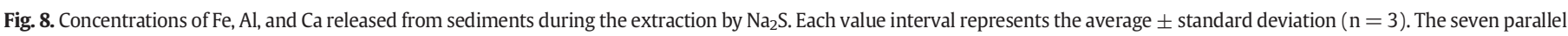

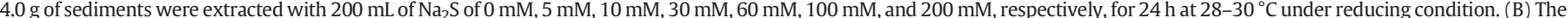

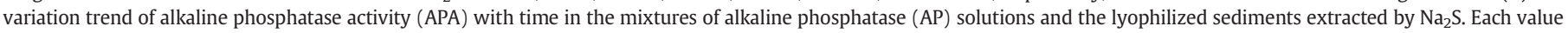

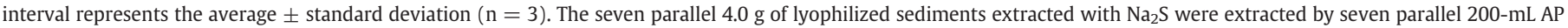
solutions ( $\left.1 \mathrm{U} \mathrm{mL}^{-1}, \mathrm{pH} 8\right)$ for $24 \mathrm{~h}$ at $28-30{ }^{\circ} \mathrm{C}$ under reducing condition.

precipitates formed by the interaction between $\mathrm{Al}$ and the surface of the organic matter particles in water (Johnson et al., 2005). Because AP is a protein, its inactivation by $\mathrm{Al}$ could be attributed to the ability of the generated $\mathrm{AlOOH}$ polynuclear hydroxy complexes to bridge and adsorb the AP (Strathmann and Myneni, 2005). According to the particle size analysis, there were indeed colloids formed in the $\mathrm{AlCl}_{3}$-containing sample in the absence of $\mathrm{Na}_{2} \mathrm{~S}$ because the particle size of some precipitates was $<100 \mathrm{~nm}$ after centrifugation (Fig. 6B). In addition, $97 \%$ of the Fe was still in the ionic state. $\mathrm{Fe}^{2+}$ and $\mathrm{NO}_{3}^{-}$can easily produce hydroxyl radicals $(\cdot \mathrm{OH})$, which degrade organic matters under natural solar irradiation (Hadjira et al., 2012; Shah et al., 2015). A previous study has reported that the $\mathrm{Fe}^{2+}+$ ascorbic acid-induced inhibition of the APA is related to the generation of the hydroxyl radical $(\bullet \mathrm{OH})$, the most potent free radical known (Pintus et al., 2018). More specifically, Ohyashiki et al. (Ohyashiki et al., 1994) have reported that the oxidative damage-induced reduction of APA will be induced by the $\mathrm{Fe}^{2+}+$ ascorbic acid system; this indicates that the APA is irreversibly inhibited via the modification of the $\mathrm{Mg}^{2+}$-binding sites of AP during the early steps of the oxidation process. Therefore, the inactivation of APA by Fe in anaerobic ecosystems is mainly attributed to the destruction of AP by $\bullet \mathrm{OH}$. The thermodynamic state of $\mathrm{Ca}^{2+}$ was maintained; Ca was present as dissolved ions without the production of precipitates. $\mathrm{Ca}^{2+}$ could substitute the $\mathrm{Mg}^{2+}$ in the active sites of the AP; as a result, the maximal APA was approximately $40 \%$ of the activity of unsubstituted AP. If $\mathrm{Ca}^{2+}$ is present in sufficient amounts, it competes with $\mathrm{Zn}^{2+}$ for binding to the active sites of AP and ultimately displaces $\mathrm{Zn}^{2+}$ from the active sites, virtually eliminating the APA (Hoylaerts et al., 2015). Additionally, a novel and interesting finding was reported in the present study: $\mathrm{S}^{2-}$ can significantly deactivate AP. Therefore, we further analyzed the samples after the reaction of AP with $\mathrm{S}^{2-}$ using ICP-MS. The results indicated that the molar ratio of the intrinsic $\mathrm{Zn}^{2+}$ and $\mathrm{Mg}^{2+}$ bound to the enzyme was 2.8:1 (Fig. 7), which is consistent with the finding of a previous study (Anderson et al., 1975). The content of $\mathrm{Zn}^{2+}$ significantly decreased after the extraction process with $\mathrm{Na}_{2} \mathrm{~S}$ because the $\mathrm{Zn}^{2+}$ embedded in the AP could be eliminated by $\mathrm{S}^{2-}$. $\mathrm{S}^{2-}$ strongly combines with $\mathrm{Zn}^{2+}$, forming $\mathrm{ZnS}$ precipitates during the incubation of the samples (Kaksonen et al., 2003). However, the $\mathrm{Mg}^{2+}$ content did not decrease following the extraction process with $S^{2-}$ because the saturation index of the components in the samples containing $\mathrm{Mg}^{2+}$ and $\mathrm{S}^{2-}$ was negative, and $100 \%$ of the $\mathrm{Mg}^{2+}$ could be dissolved in these samples (Table S6 and Table S7).
According to the thermodynamic state analysis, $\mathrm{Al}^{3+}$ and $\mathrm{S}^{2-}$ hardly reacted in the solution during incubation; however, $\mathrm{S}^{2-}$ could induce the coagulation of the $\mathrm{AlOOH}$ colloids to form precipitates because $\mathrm{Al}$ hydroxide colloids have positive charges, whereas $\mathrm{S}^{2-}$ is negatively charged (Zhu et al., 2011). Therefore, the particle size of precipitates in the sample containing $\mathrm{AlCl}_{3}$ following the addition of $\mathrm{Na}_{2} \mathrm{~S}$ was smaller than that of the precipitates formed without $\mathrm{Na}_{2} \mathrm{~S}$ addition because most $\mathrm{AlOOH}$ colloids had coagulated into larger particles due to the activity of $\mathrm{S}^{2-}$ and had separated from the solution during centrifugation (Fig. 6B). Therefore, the APA in the $\mathrm{Al}^{3+}$-containing sample (after $\mathrm{S}^{2-}$ addition) was recovered mainly due to the elimination of the AlOOH colloids and $\mathrm{S}^{2-}$, which occurred following the adsorption and coagulation of the AlOOH colloids. The APA was not restored in the $\mathrm{Ca}^{2+}$-containing samples after $\mathrm{S}^{2-}$ addition because the $\mathrm{Ca}^{2+}$ could not be combined with $\mathrm{S}^{2-}$. Both the intrinsic $\mathrm{Ca}^{2+}$ plus the newly added free $S^{2-}$ could synergistically inhibit the APA, resulting in a lower APA value than that without $\mathrm{S}^{2-}$ addition. Based on the SEMEDS and XRD results, the precipitate formed by $\mathrm{Fe}^{2+}$ and $\mathrm{S}^{2-}$ is probably $\mathrm{FeS}$ because the Fe/S ratio was close to $1: 1$, and this was confirmed by the results of the thermodynamic simulation analysis. Thus, the APA increased because both $\mathrm{Fe}^{2+}$ and $\mathrm{S}^{2-}$ could be simultaneously removed from the system.

\subsection{Effect of sulfate reduction on enzyme activity}

As shown in Fig. 8A, the content of $\mathrm{Al}$ decreased as the $\mathrm{S}^{2-}$ content increased because the $\mathrm{AlOOH}$ colloids were removed from the supernatant by $\mathrm{S}^{2-}$. Therefore, $\mathrm{S}^{2-}$ accumulation could reduce the Al content from the overlying water or pore water in the sediments. Additionally, the content of soluble $\mathrm{Fe}$ increased with the $S^{2-}$ concentration $(<10 \mathrm{mM})$ in the slurry, which was probably caused by the $\mathrm{Fe}(\mathrm{III})$ (hydr)oxides being reductively dissolved by the free sulfide. Therefore, Fe could be released from the sediment under reducing conditions (Kopáček et al., 2005). Subsequently, the Fe content began to decrease as the $\mathrm{S}^{2-}$ content increased $(>10 \mathrm{mM})$, which indicated that the released $\mathrm{Fe}$ (II) combined with the free sulfide to generate FeS, thereby outpacing the reductive dissolution of Fe(III) (hydr)oxides. Therefore, sulfate reduction could promote the release of Fe at the beginning of the reaction; the Fe was then fixed by the accumulated sulfides as the sulfate reduction gradually became intense. 
In Fig. 8B, the APAs in slurries extracted using $\mathrm{Na}_{2} \mathrm{~S}(<30 \mathrm{mM})$ were lower than those in the control samples; this was probably because the $\mathrm{Fe}^{2+}$ released from the sediments and most of the AlOOH colloids had not been removed by the free sulfides and other trace metal ions that had not been coupled due to the insufficient amount of free $\mathrm{S}^{2-}$. However, excessive $\mathrm{Na}_{2} \mathrm{~S}(>200 \mathrm{mM})$ could also reduce the APA, compared to the case when the resuspended sediments were extracted using $100 \mathrm{mM} \mathrm{Na}_{2} \mathrm{~S}$. This could be explained by the $\mathrm{S}^{2-}$-mediated inactivation of the AP in the presence of excessive amounts of $\mathrm{S}^{2-}$. In contrast to the macro metals ( $\mathrm{Al}, \mathrm{Fe}$, and $\mathrm{Ca}$ ), $\mathrm{SO}_{4}^{2-}$ inhibited the APA relatively weakly. The Fe and Al contents directly determined the final APA because $\mathrm{Ca}$ could not chemically combine with the free sulfides. Therefore, the APA increased when the molar ratio of the free sulfides to the sediments (which contained $1 \mathrm{Fe}$ and $6 \mathrm{Al}$ ) was between 6 and 10, while the APA was inhibited when this ratio was $<6$ or higher than 10 .

\section{Conclusions}

Macro metal ions ( $\mathrm{Al}, \mathrm{Fe}$, and Ca ions) can markedly inhibit the APA and further reduce the efficiency of OP hydrolysis. This prevents $\mathrm{PO}_{4}^{3-}$ overload from causing eutrophication, but $\mathrm{S}^{2-}$ generation following sulfate reduction can alleviate the $\mathrm{Al}$ and $\mathrm{Fe}$ ion-mediated inhibition of APA via the elimination of $\mathrm{AlOOH}$ colloids and $\mathrm{Fe}^{2+}$ in anaerobic conditions. This can increase the APA, which improves the hydrolysis of OP. However, high APA can be reduced only when excess amounts of dissolved $\mathrm{S}^{2-}$ are accumulated, because dissolved $\mathrm{S}^{2-}$ can inhibit the APA via the removal of two $\mathrm{Zn}^{2+}$ from the active sites (M1 and M2) of AP. Therefore, the risk of $\mathrm{PO}_{4}^{3-}$ release from OP by the action of AP should be taken seriously during the initial stage of the anaerobic production of $\mathrm{S}^{2-}$ in anoxic ecosystems.

\section{Declaration of Competing Interest}

The authors declare that they have no known competing financial interests or personal relationships that could have appeared to influence the work reported in this paper.

\section{Acknowledgment}

This study was supported by the Strategic Priority Research Program of the Chinese Academy of Sciences (Grant No.:XDA23050203) and the National Natural Science Foundation of China (Grant No.: 41373100). Additional support was provided by the Key Project of Research and Development Plan of Yantai (Grant No.: 2018ZHGY083) and the Key Research and Development Program of Shandong Province (Grant No. 2019GSF109002).

\section{Appendix A. Supplementary data}

Supplementary data to this article can be found online at https://doi. org/10.1016/j.scitotenv.2019.134151.

\section{References}

Ahlgren, J., Tranvik, L., Gogoll, A., Waldeback, M., Markides, K., Rydin, E., 2005. Sediment depth attenuation of biogenic phosphorus compounds measured by P-31 NMR. Environmental Science \& Technology 39, 867-872.

Anderson, R.A., Bosron, W.F., Kennedy, F.S., Vallee, B.L., 1975. Role of magnesium in escherichia-coli alkaline-phosphatase. Proceedings of the National Academy of Sciences of the United States of America. vol. 72, pp. 2989-2993.

Brunel, C., Cathala, G., 1973. Activation and inhibition processes of alkaline-phosphatase from bovine brain by metal-ions $\mathrm{Mg}^{2+}$ and $\mathrm{Zn}^{2+}$. Biochim. Biophys. Acta 309, $104-115$.

Chen, M., Li, X., Shi, Q., Zhang, Z., Xu, S., 2019. Hydrogen sulfide exposure triggers chicken trachea inflammatory injury through oxidative stress-mediated FOS/IL8 signaling. J. Hazard. Mater. 368, 243-254.

Corpas, F.J., Barroso, J.B., Gonzalez-Gordo, S., Munoz-Vargas, M.A., Palma, J.M., 2019. Hydrogen sulfide: a novel component in Arabidopsis peroxisomes which triggers catalase inhibition. J. Integr. Plant Biol. 61, 871-883.
Dai, Y., Wu, J., Ma, X., Zhong, F., Cui, N., Cheng, S., 2017. Increasing phytoplanktonavailable phosphorus and inhibition of macrophyte on phytoplankton bloom. Sci. Total Environ. 579, 871-880.

Hadjira, B., Tahar, S., Nadia, K., Kamel, D., 2012. Kinetic and analytical study of the photoinduced degradation of monuron by nitrates and nitrites under irradiation or in the dark. Photochemical \& Photobiological Sciences Official Journal of the European Photochemistry Association \& the European Society for Photobiology 11, 1339-1345.

Hjorleifsson, J.G., Asgeirsson, B., 2016. Cold-active alkaline phosphatase is irreversibly transformed into an inactive dimer by low urea concentrations. Biochimica Et Biophysica Acta-Proteins and Proteomics 1864, 755-765.

Holtz, K.M., Kantrowitz, E.R., 1999. The mechanism of the alkaline phosphatase reaction: insights from NMR, crystallography and site-specific mutagenesis. FEBS Lett. 462, 7-11.

Hoylaerts, M.F., Van Kerckhoven, S., Kiffer-Moreira, T., Sheen, C., Narisawa, S., Millan, J.L., 2015. Functional significance of calcium binding to tissue-nonspecific alkaline phosphatase. PLoS One 10. https://doi.org/10.1371/journal.pone.0119874.

Huang, R., Wan, B., Hultz, M., Diaz, J.M., Tang, Y., 2018. Phosphatase-mediated hydrolysis of linear polyphosphates. Environmental Science \& Technology 52, 1183-1190.

Ivanoff, D.B., Reddy, K.R., Robinson, S., 1998. Chemical fractionation of organic phosphorus in selected histosols. Soil Sci. 163, 36-45.

Johnson, S.B., Brown, G.E., Healy, T.W., Scales, P.J., 2005. Adsorption of organic matter at mineral/water interfaces. 6. Effect of inner-sphere versus outer-sphere adsorption on colloidal stability. Langmuir 21, 6356-6365.

Jong, T., Parry, D.L., 2003. Removal of sulfate and heavy metals by sulfate reducing bacteria in short-term bench scale upflow anaerobic packed bed reactor runs. Water Res. 37 3379-3389.

Kaksonen, A.H., Riekkola-Vanhanen, M.L., Puhakka, J.A., 2003. Optimization of metal sulphide precipitation in fluidized-bed treatment of acidic wastewater. Water Res. 37, 255-266.

Kopáček, J., Borovec, J., Hejzlar, J., Ulrich, K.-U., Norton, S.A., Amirbahman, A., 2005. Aluminum control of phosphorus sorption by lake sediments. Environmental Science \& Technology 39, 8784-8789.

Kraal, P., Dijkstra, N., Behrends, T., Slomp, C.P., 2017. Phosphorus burial in sediments of the sulfidic deep Black Sea: key roles for adsorption by calcium carbonate and apatite authigenesis. Geochim. Cosmochim. Acta 204, 140-158.

Labry, C., Delmas, D., Youenou, A., Quere, J., Leynaert, A., Fraisse, S., Raimonet, M., Ragueneau, O., 2016. High alkaline phosphatase activity in phosphate replete waters: the case of two macrotidal estuaries. Limnol. Oceanogr. 61, 1513-1529.

Le Du, M.H., Millan, J.L., 2002. Structural evidence of functional divergence in human alkaline phosphatases. J. Biol. Chem. 277, 49808-49814.

Le Du, M.H., Stigbrand, T., Taussig, M.J., Menez, A., Stura, E.A., 2001. Crystal structure of alkaline phosphatase from human placenta at 1.8 a resolution - implication for a substrate specificity. J. Biol. Chem. 276, 9158-9165.

Liu, J., Cheng, X., Qi, X., Li, N., Tian, J., Qiu, B., Xu, K., Qu, D., 2018. Recovery of phosphate from aqueous solutions via vivianite crystallization: thermodynamics and influence of pH. Chem. Eng. J. 349, 37-46.

Lü, C., Wang, B., He, J., Vogt, R.D., Zhou, B., Guan, R., Zuo, L., Wang, W., Xie, Z., Wang, J., Yan, D., 2016. Responses of organic phosphorus fractionation to environmental conditions and lake evolution. Environmental Science \& Technology 50, 5007-5016.

Luo, H., Zhang, H., Long, R.A., Benner, R., 2011. Depth distributions of alkaline phosphatase and phosphonate utilization genes in the North Pacific subtropical gyre. Aquat. Microb. Ecol. 62, 61-69.

Migaszewski, Z.M., Gałuszka, A., Dołęgowska, S., 2018. Arsenic in the Wiśniówka acid mine drainage area (south-central Poland) - mineralogy, hydrogeochemistry, remediation. Chem. Geol. 493, 491-503.

Millan, J.L., 2006. Alkaline phosphatases: structure, substrate specificity and functional relatedness to other members of a large superfamily of enzymes. Purinergic signalling 2, 335-341.

Mornet, E., Stura, E., Lia-Baldini, A.S., Stigbrand, T., Menez, A., Le Du, M.H., 2001. Structura evidence for a functional role of human tissue nonspecific alkaline phosphatase in bone mineralization. J. Biol. Chem. 276, 31171-31178.

Nicholls, P., Marshall, D.C., Cooper, C.E., Wilson, M.T., 2013. Sulfide inhibition of and metabolism by cytochrome c oxidase. Biochem. Soc. Trans. 41, 1312-1316.

Ohyashiki, T., Kumada, Y., Hatanaka, N., Matsui, K., 1994. Oxygen radical-induced inhibition of alkaline-phosphatase activity in reconstituted membranes. Arch. Biochem. Biophys. 313, 310-317.

Pintus, E., Kadlec, M., Jovicic, M., Sedmikova, M., Ros-Santaella, J.L., 2018. Aminoguanidine protects boar spermatozoa against the deleterious effects of oxidative stress. Pharmaceutics 10. https://doi.org/10.3390/pharmaceutics10040212.

Ragot, S.A., Kertesz, M.A., Buenemann, E.K., 2015. phoD alkaline phosphatase gene diversity in soil. Appl. Environ. Microbiol. 81, 7281-7289.

Salar, U., Khan, K.M., Iqbal, J., Ejaz, S.A., Hameed, A., al-Rashida, M., Perveen, S., Tahir, M.N., 2017. Coumarin sulfonates: new alkaline phosphatase inhibitors; in vitro and in silico studies. Eur. J. Med. Chem. 131, 29-47.

Sayler, G.S., Puziss, M., Silver, M., 1979. Alkaline-phosphatase assay for freshwater sediments - application to perturbed sediment systems. Appl. Environ. Microbiol. 38, 922-927.

Shah, N.S., He, X., Khan, J.A., Khan, H.M., Boccelli, D.L., Dionysiou, D.D., 2015. Comparative studies of various iron-mediated oxidative systems for the photochemical degradation of endosulfan in aqueous solution. J. Photochem. Photobiol. A Chem. 306, 80-86.

Shinohara, R., Imai, A., Kawasaki, N., Komatsu, K., Kohzu, A., Miura, S., Sano, T., Satou, T., Tomioka, N., 2012. Biogenic phosphorus compounds in sediment and suspended particles in a shallow eutrophic lake: a 31P-nuclear magnetic resonance (31P NMR) study. Environmental Science \& Technology 46, 10572-10578.

Strathmann, T.J., Myneni, S.C.B., 2005. Effect of soil fulvic acid on nickel(II) sorption and bonding at the aqueous-boehmite $(\gamma-\mathrm{AlOOH})$ Interface. Environmental Science \& Technology 39, 4027-4034. 
Takano, Y., Mori, H., Kaneko, T., Ishikawa, Y., Marumo, K., Kobayashi, K., 2006. Phosphatase and microbial activity with biochemical indicators in semi-permafrost active layer sediments over the past 10,000 years. Appl. Geochem. 21, 48-57.

Tan, X., Wang, Z., Lu, G., He, W., Wei, G., Huang, F., Xu, X., Shen, W., 2017. Kinetics of soil dehydrogenase in response to exogenous Cd toxicity. J. Hazard. Mater. 329, 299-309.

Tan, X., Machmuller, M.B., Wang, Z., Li, X., He, W., Cotrufo, M.F., Shen, W., 2018. Temperature enhances the affinity of soil alkaline phosphatase to $\mathrm{Cd}$. Chemosphere 196 214-222.

Tang, Z., Chen, H., He, H., Ma, C., 2019. Assays for alkaline phosphatase activity: progress and prospects. TrAC Trends Anal. Chem. 113, 32-43.

Thompson, R.W., Valentine, H.L., Valentine, W.M., 2003. Cytotoxic mechanisms of hydrosulfide anion and cyanide anion in primary rat hepatocyte cultures. Toxicology $188,149-159$

Tian, H., Zhao, Y., Megharaj, M., He, W., 2018. Arsenate inhibition on kinetic characteristics of alkaline phosphatase as influenced by pH. Ecol. Indic. 85, 1101-1106.

Turner, B.L., Paphazy, M.J., Haygarth, P.M., McKelvie, I.D., 2002. Inositol phosphates in the environment. Philosophical Transactions of the Royal Society of London Series BBiological Sciences 357, 449-469.

Turner, B.L., Cheesman, A.W., Godage, H.Y., Riley, A.M., Potter, B.V.L., 2012. Determination of neo- and D-chiro-inositol hexakisphosphate in soils by solution P-31 NMR spectroscopy. Environmental Science \& Technology 46, 4994-5002.

Vig, K., Megharaj, M., Sethunathan, N., Naidu, R., 2003. Bioavailability and toxicity of cadmium to microorganisms and their activities in soil: a review. Adv. Environ. Res. 8 121-135.

Zamparas, M., Zacharias, I., 2014. Restoration of eutrophic freshwater by managing internal nutrient loads. A review. Sci. Total Environ. 496, 551-562.

Zavaczki, E., Jeney, V., Agarwal, A., Zarjou, A., Oros, M., Katko, M., Varga, Z., Balla, G., Balla, J., 2011. Hydrogen sulfide inhibits the calcification and osteoblastic differentiation of vascular smooth muscle cells. Kidney Int. 80, 731-739.

Zhang, H., Yu, J., Zhou, S., 2014. Spatial distribution of $\mathrm{As}, \mathrm{Cr}, \mathrm{Pb}, \mathrm{Cd}, \mathrm{Cu}$, and $\mathrm{Zn}$ in the water and sediment of a river impacted by gold mining. Mine Water Environ. 33, 206-216.
Zhang, W., Jin, X., Rong, N., Li, J., Shan, B., 2016. Organic matter and pH affect the analysis efficiency of 31P-NMR. J. Environ. Sci. 43, 244-249.

Zhang, X., Deng, J., Xue, Y., Shi, G., Zhou, T., 2016. Stimulus response of Au-NPs@GMP-Tb core-shell nanoparticles: toward colorimetric and fluorescent dual-mode sensing of alkaline phosphatase activity in algal blooms of a freshwater Lake. Environmental Science \& Technology 50, 847-855.

Zhao, G., Sheng, Y., Jiang, M., Zhou, H., Zhang, H., 2019. The biogeochemical characteristics of phosphorus in coastal sediments under high salinity and dredging conditions. Chemosphere 215, 681-692.

Zhou, Y.Y., Li, J.Q., Zhang, M., 2002. Temporal and spatial variations in kinetics of alkaline phosphatase in sediments of a shallow Chinese eutrophic lake (Lake Donghu). Water Res. 36, 2084-2090.

Zhou, H., Sheng, Y., Zhao, X., Gross, M., Wen, Z., 2018. Treatment of acidic sulfatecontaining wastewater using revolving algae biofilm reactors: sulfur removal performance and microbial community characterization. Bioresour. Technol. 264, 24-34.

Zhu, G., Zheng, H., Zhang, Z., Tshukudu, T., Zhang, P., Xiang, X., 2011. Characterization and coagulation-flocculation behavior of polymeric aluminum ferric sulfate (PAFS). Chem. Eng. J. 178, 50-59.

Zhu, Y., Wu, F., He, Z., Guo, J., Qu, X., Xie, F., Giesy, J.P., Liao, H., Guo, F., 2013. Characterization of organic phosphorus in lake sediments by sequential fractionation and enzymatic hydrolysis. Environmental Science \& Technology 47, 7679-7687.

Zhu, Y, Wu, F., He, Z, Giesy, JP. Feng W., Mu, Y, Feng C. Zhao, X, Liao, H., Tang, Z, 2015. Influence of natural organic matter on the bioavailability and preservation of organic phosphorus in lake sediments. Chem. Geol. 397, 51-60.

Zhu, Y., Wu, F., Feng, W., Liu, S., Giesy, J.P., 2016. Interaction of alkaline phosphatase with minerals and sediments: activities, kinetics and hydrolysis of organic phosphorus. Colloids Surf. A Physicochem. Eng. Asp. 495, 46-53. 